\title{
ESTUDO DA INTERACÃO DE GENÓTIPOS $\times$ AMBIENTES PARA A CULTURA DO ALGODÃO (Gossypium sp.) NA REGIÃO ORIENTAL DO PARAGUAI
}

LUIS MIGUEL ANGEL RAIDAN GONZALEZ

Orientador: Prof. Dr. ROLAND VENCOVSKY

Dissertação apresentada à Esco la Superior de Agricultura "Iuiz de Queiroz", da Universidade de São Paulo, para obtenção do tí tulo de Mestre em Agronomia = Area de Concentração: Genética e Melhoramento de Plantas. 
633.51 RaidánGonzalez, Luis. Miguel Mgel.,

R149e Estudo da interaça ${ }^{a} \mathrm{~d} \otimes \mathrm{g} \diamond$ óttpos $\mathrm{x}$ ambientes para a cultura do algcdão (GoMypium" sp.) na região o riental do Paraguai. Piracicaba, 1988.

9lp. ilus.

Diss. (Mestre\} - ESAL

Bibliografia

1. Algodão - Genética ecológica - Paraguai (região oriental) 2. 2. Algodão - Interação genótipo $x$ ambiente - Paraguai (região oriental). 3. Algodão M::Ihorarrento - Paraguai (região oriental). I . Escola Superior de Agricultura "Luiz de Queiroz", Piraci caba. 
ESTUDO DA INTERAÇÃO DE GENOTIPOS $x$ AMBIENTES PARA A CULTURA DO ALGODÃO (Gossypium sp.) NA REGIÃO ORIENTAL DO PARAGUAI

\section{Luis Miguel Angel Raidān Gonzalez}

Aprovado em: 05/08/1988

Comissão Examinadora:

Prof. Dr. Roland Vencovsky

Prof. Dr. Isaias Olívio Geraldi

Prof. Dr. Paulo de Soúza Gonçalves
ESALQ/USP

ESALQ/USP

IAC/Campinas

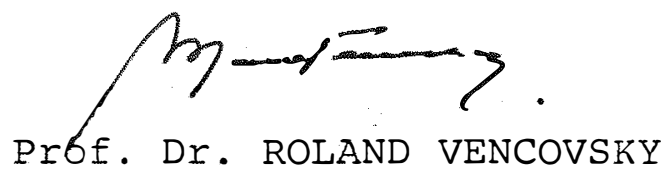

orientador 


\section{AGRADECIMENTOS}

Ao Prof. Dr. Roland Vencovsky pela orientação, apoio e incentivo constante durante o curso de pós-graduação;

Ao Ministério de Agricultura e Ganaderia do Paraguai, na pessoa do Ilmo. Sr. Ministro Eng. Agr. Hernando Bertoni, pela oportunidade concedida para a realização docur so;

À Organização dos Estados Americanos (O.E.A.) pela conces são da bolsa de estudos;

Ao Eng9 Agr9 Luís Alberto Alvarez, coordenador do Projeto de Investigação e Experimentação Algodoeira (P.I.E.A) pelo fornecimento dos dados experimentais;

Ao Eng9 Agr9 Gregório Raidán pela atenção e estimulo;

Aos Professores do Departamento de Genética, pelos ensinamen tos recebidos durante o curso;

Ao Eng9 Agr9 Cirilo Centurión pelo apoio incondicional.

À Eng9 Agr9 Rosita Benitez Portillo pelas sugestões;

Ao Eng9 Agr9 Telmo Canton pelo estimulo e amizade;

Ao Prof. Dr. Roberto A.A. Torres pelo processamento de dados e sugestões;

Ao Prof. Dr. Cosme Damião Cruz e ao Eng9 Agr9 José Sebastião Cunha Fernanàes pelas contribuições; 
Aos colegas Graciela Gomez e Vicente Mangano pela revisão dos dados;

$\bar{A}$ bibliotecária Nilce pulga Sigrist pela revisão feita na literatura;

A todos os colegas do Departamento de Genética da ESALQ, que de uma forma ou de outra contribuiram para a realização do presente trabalho. 


\section{INDICE}

Pāgina

LISTA DE FIGURAS ..................... vi vi

LISTA DE TABELAS .................... vii vi

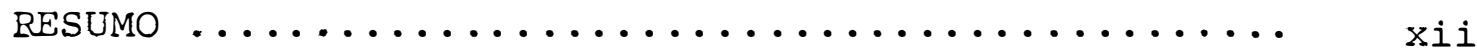

SUMMARY $\ldots \ldots \ldots \ldots \ldots \ldots \ldots \ldots \ldots \ldots \ldots \ldots \ldots \ldots \ldots \ldots \ldots$

1. INTRODUÇส̃กO ........................ 01

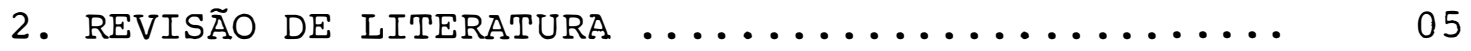

2.1. Aspectos sobre interação genótipos $x$ ambi-

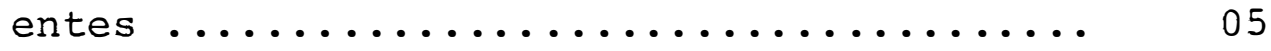

2.2. Interação genótipos $x$ ambientes em algo-

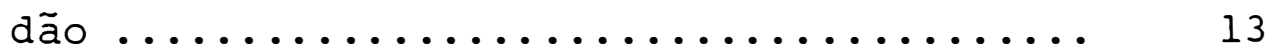

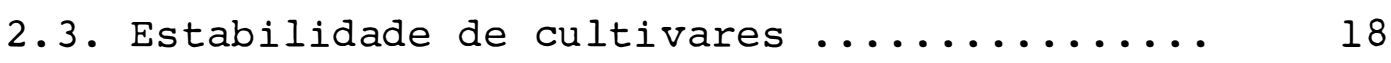

2.4. Agrupamento de ambientes ............... 25

3. MATERIAL E METODOS ..................... 30

3.1. Material ....................... 30

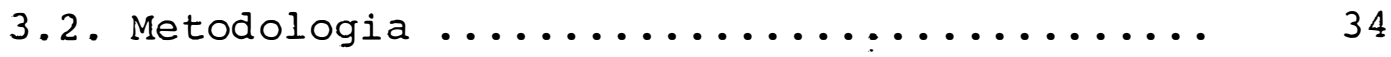

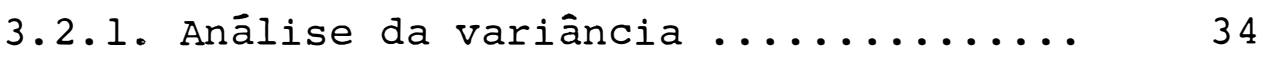

3.2.2. Análise de estabilidade .......... 37

3.2.3. Classificação de ambientes ........ 41

3.2.3.1. Similaridade ........... 41

3.2.3.2. Agrupamento .......... 43

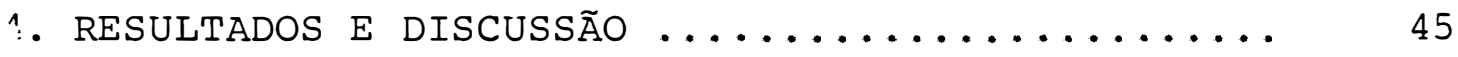

4.1. Condições gerais dos experimentos ........ 45

4.2. Análise de variância ................ 46

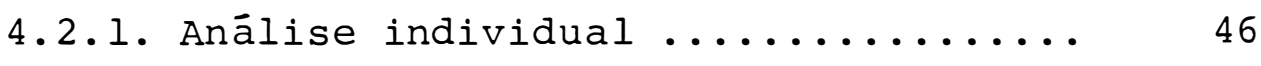

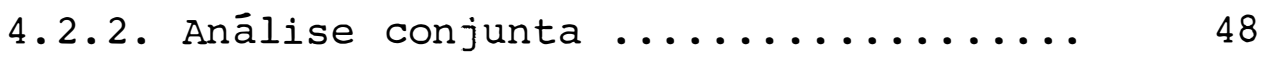


vi.

Pāgina

4.3. Análise de estabilidade ............... 55

4.4. Classificação de ambientes ............ 65

5. CONCLUSÕES ....................... 73

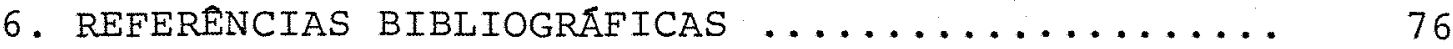

7. APENDICES $\ldots \ldots \ldots \ldots \ldots \ldots \ldots \ldots \ldots \ldots \ldots \ldots \ldots$ 
vii.

LISTA DE FIGURAS

FIGURA No

Pāgina

01 Distribuição dos ensaios regionais nos diferentes locais da região oriental do Paraguai. Anos agricolas 1985/86, 1986 $/ 87 \ldots \ldots \ldots \ldots \ldots \ldots \ldots \ldots \ldots \ldots \ldots \ldots \ldots \ldots \ldots \ldots \ldots$

02 Representação gráfica da produtividade de três genōtipos de algodão (Gossupium sp.) em função dos índices ambientais. Ano agrícola $1985 / 86 \ldots \ldots \ldots \ldots \ldots$

03

Representação gráfica da produtividade de nove genōtipos de algodão (Gossypium sp.) em função dos indices ambientais. Ano agrícola $1986 / 87$............ 
viii.

\section{LISTA DE TABELAS}

TABELA NO

página

01 Genōtipos utilizados como tratamentos no experimento do ano $1985 / 86$......

Genótipos utilizados como tratamentos no experimento do ano $1986 / 87$......

Esquema da anālise individual da va-

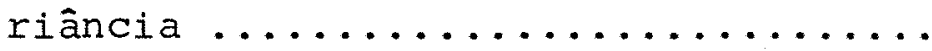

Esquema da anālise conjunta da variân

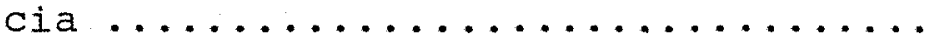

05 Esquema da análise de variância segundo mētodo de: EBERHART \& RUSSELL (1966)

Análise conjunta da variância dos dados de produtividade média de algodão em caroço em $\mathrm{kg} / 20 \mathrm{~m}^{2}$ de três genótipos de algodão em seis localidades da região oriental do paraguai. Ano agri cola $1985 / 86 \ldots \ldots \ldots \ldots \ldots \ldots$

07 Produtividade média em $\mathrm{kg} / 20 \mathrm{~m}^{2}$ de três genōtipos de algodão em seis localidá des da região orienta? do Paraguai, média $(\bar{y})$; variância do erro $\left(s^{2}\right)$ e coeficiente de variação de cada experimento. Ano ágrícola 1985/86 ..... 
Análise conjunta da variāncia dos dados de produtividade média de algodão em caroço em $\mathrm{kg} / 20 \mathrm{~m}^{2}$ de nove genótipos de algodão em seis localidades da região Oriental do Paraguai. Ano agri cola $1986 / 87 \ldots \ldots \ldots \ldots \ldots \ldots$

Produtividade média em $\mathrm{kg} / 20 \mathrm{~m}^{2}$ de três genótipos de algodão (Gossypium $\mathrm{sp)}$ ) em seis localidades da região oriental do Paraguai; média $(\bar{y})$; variāncia do erro $\left(s^{2}\right)$ e coeficiente de variação (CV\%) de cada ensaio. Ano agrí cola $1986 / 87 \ldots \ldots \ldots \ldots \ldots \ldots \ldots$

10 Análise de variância conjunta dos dados de produtividade média de algodão em caroço de três genótipos em 6 localidades da região Oriental do Paraguai, segundo a metodologia de EBER HART \& RUSSELL (1966). Ano agricola $1985 / 86 \ldots \ldots \ldots \ldots \ldots \ldots \ldots \ldots \ldots$

11 Estimativas dos parâmetros de estabilidade de produtividade de algodão em caroço de três genótipos sequndo a metodologia de EBERHART \& RUSSELI (1966). Ano agrícola $1985 / 86$............ 
Anālise de variância conjunta dos dados de produtividade média de algodão em caroço de nove genótipos em 6 localidades da região Oriental do Paraguai, segundo a metodologia de EBER HART \& RUSSELL (1966). Ano agríco1a $1986 / 87 \ldots \ldots \ldots \ldots \ldots \ldots$

13 Estimativas dos parāmetros de estabilidade de produtividade de algodão em caroço de nove genótipos (Gossypium sp), segundo a metodologia de EBERHART \& RUSSELL (1966). Ano agrícola 1986/ $87 \ldots \ldots \ldots \ldots \ldots \ldots \ldots \ldots \ldots \ldots \ldots \ldots \ldots \ldots \ldots \ldots \ldots$

14 Matriz da soma dos quadrados dos efei tos da interação genótipos $x$ locais.

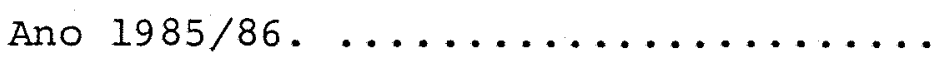

15 Matriz das distâncias $\left(\mathrm{d}_{\mathrm{kk}}^{2},\right)$, obtidas a partir dos efeitos da interação genōtipos x locais. Ano 1985/86 .....

16 Agrupamento dos locais segundo a meto dologia de K.D. Tocher (RAO, 1952) pa ra o ano $1985 / 86 \ldots \ldots \ldots \ldots \ldots$

17 Matriz da soma dos quadrados dos efei tos da interação genótipos $x$ locais. Ano $1986 / 87 \ldots \ldots \ldots \ldots \ldots \ldots \ldots$. . . . . . . . . . . 
Matriz de distâncias $\left(\mathrm{d}_{\mathrm{k} k^{\prime}}^{2}\right)$ obtidas a partir da interação genótipos $x$ locais. Ano $1986 / 87$............

19 Agrupamento de locais segundo a metodologia de K.D. Tocher (RAO, 1952), pa ra o ano $1986 / 87 \ldots \ldots \ldots \ldots \ldots$ 
xii.

ESTUDO DA INTERAÇÃO DE GENOTIPOS POR AMBIENTES PARA A CUITURA DO ALGODÃO (Gossypium sp.) NA REGIÃO ORIENTAL DO PARAGUAI

Autor: LUIS MIGUEL ANGEL RAIDĀN GONZALEZ Orientador: Prof. Dr. ROLAND VENCOVSKY

\section{RESUMO}

Estudou-se a estabilidade de 10 genótipos (vâ riedades e linhagens promissoras) de algodoeiro anual (Gossy pium sp.) em seis localidades da região Oriental do Paraguai durante os anos 1985/86 e 1986/87, utilizando-se a metodolo gia de EBERHART \& RUSSELL (1966).

Realizou-se também estudos de zoneamento de ambientes, a partir da anālise das interações genōtipos x lo cais, em que estas foram agrupados de acordo com a simila ridade de seus padrões de interação. Para ambos os estu- dos foram utilizados dados de produtividade de algodão em ca roço em $\mathrm{kg} / 20 \mathrm{~m}^{2}$, fornecidos pelo Ministërio de Agricultura e Pecuāria atravēs do Programa Nacional de Algodão e o Proje to de Investigação e Experimentação Algodoeira (P.I.E.A.) .

Foi utilizado o delineamento experimental de blocos casualizados, sendo a ārea da parcela experimental constituida por três fileiras de 20 metros de comprimento, espaçados de Im $x$ 0,25m, aproveitando-se apenas a fileira central para a coleta dos dados. 
xiil.

Comparando-se os quadrados médios através do teste $F$, verificou-se nos dois anos agrícolas, valores signi ficativos para os efeitos de genótipos, locais, interações genótipos x locais, ambiente linear e desvios de regressão. Em 1985/86 a linhagem SP510 x.P-279-100 mostrou-se estável e de adaptação geral. A variedade Reba P-279 mostrou estabilidade e adaptação especifica a ambientes promissores. A linhagem SP510 x P-279-22 mostrou adaptação geral, porém com uma média de produtividade inferior à média geral.

Em 1986/87, os genótipos SP510 x P-279-40/42, Reba P-279 e SP-510 x P-279-38/41 apresentaram maior capacidade de respostas aos estimulos ambientais favoráveis. No en tanto os genótipos SP510 x P-279-32, SP510 x P-279-29/43, SP510 x P-279-100 mostraram estabilidade e adaptação a uma ampla faixa de ambientes. As linhagens SP510 xP-279-28/39 e Tamcot SP-21-S apresentaram pouca previsibidade, ou seja, menor grau de ade quação ao modelo.

A classificação dos locais segundo a metodolo gia utilizada mostrou inconsistência no agrupamento de um ano a outro, impedindo a realização de um zoneamento de ambien tes, fato atribuido à insuficiência dos dados utilizados e a grande complexidade do problema. 
A STUDY ON GENOTYPE BY ENVIRONMENTAL INTERACTION OF UPLAND COTTON (GOSsypium sp.) IN THE EASTERN REGION OF PARAGUAY.

Author: LUIZ MIGUEL ANGEL RAIDAN GONZALEZ Adviser: Prof. Dr. ROLAND VENCOVSKY

SUMMARY

The stability of 10 upland cotton (Gossypium sp) genotypes (varieties and elite inbred lines) was studied in six sites of the eastern region of Paraguay, during 1.985/ 86 and $1.986 / 87$

An investigation was also carried out to permit clustering the six sites in agroecological zones, according to their genotype $\mathrm{x}$ location interaction patterns.

For both studies, data on cotton seed weight of trials conducted by the National Cotton Research Program were taken.

Experiments consisted of randomized complete blocks, with plots containing three $20 \mathrm{~m}$ log rows, spaced $1 \mathrm{~m}$ apart with $25 \mathrm{~m}$, between plants. Cotton seed weight was evaluated in the middle row.

Analysis of variance indicated significance of the genotypes, locations, genotypes x locations, interactions, environments Iinear and deviations from regression mean squares. 
$\mathrm{XV}$.

In 1985/86, inbred Iine SP510 x p-279-100 showed stability and a pattern of general adaptation. Variety Reba P-279, on the other hand, showed stability but specific adaptation of favorable environments. Inbred line sp-510 x P-279-32 exhibited general adaptation but low yield potential. In 1986/87, stability and pattern of general adaptation was shown by inbred line SP510 x P-279-32. However inbred lines SP510 x P-279-28/39 and TAMCOT SP-21-S were less stable and adaptative to superior environments only. The remaining genotypes showed average stability pattern and also more adaptation to better environment conditions.

The clustering of locations in group was inconsistent over years; no typical agroecological zone was therefore detected. This result was atribuited to the complexity of the type of problem and to insuficiency of experimental data. 


\section{INTRODUGÃO}

A cotonicultura representa para o Paraguai uma das mais importantes atividades agrícolas, ocupando lugar de destaque pelo valor de seus produtos no mercado interno, como matēria prima para indústria e, no externo, pela exportação de fibras.

Atualmente, a superficie cultivada com algodão (Gossypium sp) atinge aproximadamente 300.000 ha, o que representa $56,8 \%$ do total da área agrícola explorada do país, sendo a Região oriental a maior zona produtora, assim como tambēm o centro da Região Ocidental ou Chaco. A produção têxtil se incrementou de 40.500 toneladas em 1972, ano de início do Programa Nacional de Algodão, a 460.031 toneladas em 1985, representando uma taxa acumulativa média de $80 \%$ ao ano, mostrando, assim, que a produção têxtil tem uma grande importância sócio-econônica (P.I.E.A., 1986/87).

Apesar do alto padrão genético das cultivares e dos avanços nos métodos culturais utilizados, a contribui Ção ambiental presente na expressão fenotipica de um caräter é um fator que deve ser considerado pelos melhoristas de 
plantas, principalmente quando essa contribuição representa uma proporção considerāvel do valor fenotípico. o conhecimen to desta participação assume grande importância, pois a fide lidade das recomendações das cultivares diminui à medida que as expressões fenotipicas são muito influenciadas pelos efei tos ambientais, isso porque muitas vezes uma cultivar que se mostra promissora em um determinado ambiente, torna-se indesejāvel em outro, quando as condições ambientais mudam.

o sucesso do melhoramento genētico de plantas está associado ao potencial genético pertinente ao material inicial, à exploração da recombinação gênica possível e à seleção dos genōtipos superiores. Todas estas faces sofrem grandes influências do ambiente no qual o processo é desenvolvido, principalmente nas fases finais de seleção onde as diferenças são pequenas e uma interação positiva ou negativa dos genótipos com ambiente pode prejudicar a finalização do pro cesso.

O problema resulta da deficiência dos genōtipos manterem um padrão consistente de desempenho quando cultivados sob uma gama de ambientes variáveis no tempo e/ou no espaço. Isto significa que a precisão das com parações fica reduzida, desde que, para um dado conjunto de ambientes, o componente da interação corna-se parte do erro experimental. Assim, este componente torna-se grande, fican do dificil identificar um simples destaque genotípico para o referido conjunto de ambientes. Portanto, se requerem cer- 
tas modificações a introduzir no programa de melhoramento usado, sendo desaconselhável a recomendação de um único genótí po para uma ampla extensão de ambientes, na base do comporta mento médio, já que desse modo se otimiza o desempenho dos ge nótipos.

Vários métodos têm sido propostos para a análise estatistica de interações em geral, e de interações genótipos $\mathrm{x}$ ambientes em particular. Entre os métodos propostos para estudo das interações genótipos $x$ ambientes, segundo um enfoque mais direto, existem uns voltados para a de finição de "regiões de adaptação", ou seja, para a regionalí zação de locais, e outros para o estudo da estabilidade de cultivares. As duas estratēgias poderão ser de grande utili dade para o controle das interações genótipos $x$ ambientes, associadas às variações ambientais previsiveis. A eficiência da regionalização, quando realizada dentro de cada ano em estudo, será tanto maior quanto mais alta for a proporção das interações que seja devida a locais.

Estudos desenvolvidos para a regionalização pro põe a utilização de tēcnicas de análise de conglomeração ("cluster analysis") adotando-se como medida de similatidade entre os locais, o coeficiente de distância obtido a partir da matriz de estimativas dos efeitos da interação geñ́ipos x locais.

Estudos de estabilidade de cultivares sobre as combinações de locais e anos, onde os coeficientes de re- 
gressão e desvios da regressão são tomados como parâmetros para estimar estabilidade, permitiram sintetizar em poucos parâmetros, as informações obtidas dos experimentos.

o propósito do presente trabalho, dentro de suas limitações é avaliar as magnitudes da interação genōti pos $\mathrm{x}$ ambientes, caracterizando um padrão de similaridade entre os locais; assim como tambēm um estudo de estabilidą de das variedades e linhagens promissoras.

Com isto, procurou-se verificar se o melhoramento está dirigindo-se no sentido de aumentar o grau de adaptação dos genótipos às condições climáticas mais amplas e de fācil distinção, muito embora resultados significativos tenham sido encontrados para a interação genótipo $x$ ambientes, mesmo estando dentro de uma pequena região geográfica. 


\section{REVISÃO DE LITERATURA}

\subsection{AsPeCtOS SOBRE INTERAGÃO GENÓTIPOS $X$ AMBIENTES}

No processo de melhoramento genético de plantas, a influência que o amuiente exerce sobre cada genótipo tem merecido atenção especial por parte dos melhoristas de plantas, visto que as interações entre genótipos e ambientes podem interferir negativamente nos resultados finais de um programa de melhoramento.

A interação de genōtipos $x$ ambientes, ou seja, as alterações do comportamento relativo de vārios genótí pos em ambientes variáveis, quando estes são submetidos a es tudos comparativos sobre uma amplitude ambiental, geralmen te mostra diferenças na expressão final do potencial dos ge nōtipos (EBERHART \& RUSSELL, 1966). Segundo os mesmos autores, as interações estão normalmente presentes para qualquer mate rial com o qual o melhorista possa estar trabalhando, sugerindo que um programa de melhoramento poderia ser orientado para o desenvolvimento de variedades para ambientes específi cos; o aspecto negativo, neste caso, seria o grande desempe- 
nho de recursos humanos, material genético e financeiros que seriam demandados.

Para ALLARD (1961), existe uma concordância geral entre melhoristas de plantas de que interações genótipos $\mathrm{x}$ ambientes têm um importante significado para a obtenção de variedades superiores. Entretanto, é muito mais difí cil encontrar concordâncias sobre o que se deve conhecer am relação às interações genótipos $x$ ambientes e como utilizālas.

ALLARD (1971) considera que os valores dos ge nōtipos devem ser medidos em relação à um grupo particular de ambientes. Estes ambientes são, em geral, os que ocorrem num certo período de anos, num certo número de locais e dentro de uma área geográfica relativamente homogênea. As mensu rações experimentais de valores genotípicos são sempre basea das apenas numa amostra dos ambientes que existem dentro da área geográfica, e que constituem a população de ambientes.

o mesmo autor comenta que estudos sobre inte rações genōtipos $\mathrm{x}$ ambientes têm proporcionado informações sobre como eliminar as tendências de se superestimar as variâncias genéticas. Lembra ainda o autor que esta superestimação é que leva a discrepâncias entre respostas esperadas e obtidas com a seleção, adaptação de cultivares, avaliação de genótipos e estabilidade de produção.

ALIARD \& BRADSHAW (1964) classificam a variação ambiental em duas categorias: al previsivel e d) imprevisí 
vel. A primeira categoria refere-se às caracteristicas permanentes do ambiente, tais como: caracteres gerais do clima e alguns caracteres que flutuam sistematicamente como o comprimento do dia, a insolação e outros. Também se incluem nesta categoria os aspectos ambientais que são direta mente influenciados pelo homem, tais como a data e a densida de de semeadura, doses e forma de adubação, métodos e épocas de colheita e outras prāticas agronômicas. As variações imprevisiveis correspondem às flutuaçöes do clima tais como a quantidade e distribuição de chuvas, temperatura e outros fatores.

Para BASSINELLO (1984), é possível reduzir a influência de tais interações no valor dos genótipos através da quantificação das suas magnitudes, promovendô se assim o desenvolvimento de métodos mais precisos de seleção. O autor considera ainda, que aumentos na eficiência são, por outro lado, muito demorados quando somente caracte res finais como produtividade e qualidade são considerados. Acredita que o progresso real será possível somente quando forem obedecidos os passos pelos quais os caracteres finais são alcançados, sendo interessante conhecer o que pode servir para orientar o melhorista no desenvolvimento de varieda des que minimizem as interações genōtipos $x$ ambientes desfavorāveis, isto è, variedades que sejam capazes de controlar seus processos de desenvolvimento, mantendo comportamento con sistente frente às variações ambientais. 
Segundo FINLAY \& WILKINSON (1963), a habilidą de de algumas variedades cultivadas possuirem bom comportamento sob grande variação de condições ambientais, tem sido longamente apreciada pelos agrônomos e melhoristas. Atendendo à demanda por variedades melhor adaptadas à condições variáveis, Frankel (1958), citado por esses autores, aponta que o melhorista é forçado a escolher entre o melhoramento para condições ecológicas estreitamente definidas ou para con dições mais extensas, as quais incluem uma considerável variação de ambientes; objetivam, neste último caso, o desenvol vimento de variedades que possuam adaptabilidade geral. Emb ra os melhoristas tenham conhecimento de diferenças genotipicas importantes na adaptabilidade, eles não conseguiram ex plorá-las totalmente nos programas de melhoramento, devido principalmente a problemas na definição e mensuração da prō pria adaptabilidade ou da complexidade dos ambientes naturais.

FREEMAN (1973) mostra que a existência de interações entre genótipos e fatores ambientais tem sido reconhecida, há longo tempo, e cita que a referência mais antiga, a qual na verdade precede a análise da variância, foi feita por Fisher \& Mackenzie (1923). Desde então, muitos trabalhos têm sido feitos para análises estatisticas da interação genótipos $\mathrm{x}$ ambientes, tanto por estatísticos interessados no teste de não aditividade em geral, como por agrô nomos, melhoristas e geneticistas. Os métodos mais simples 
que utilizam componentes de variância quando existem interações, incluem estudos de regressão e métodos similares para análises, assim como o conceito de estabilidade. Métodos baseados em análises modificadas e outros envolvendo variáveis ambientais externas, tambēm são utilizados para a interpretação dos resultados.

Estudos realizados sobre interações genötipos $\mathrm{x}$ ambientes demonstraram que a regressão foi utilizada pela primeira vez por YATES \& COCHRAN (1938), analisando grupos de experimentos. Nestes, o grau de associação entre diferen Ças varietais pôde ser verificado pelo cálculo da regressão dos rendimentos das variedades isoladas sobre os rendimentos médios de todas as variedades, mostrando assim que a regressão explicava grande parte da interação em uma série de experimentos de cevada.

o método de regressão foi tambēm usado por PERKINS \& JINKS (1968) para estimação de parâmetros em um mo delo genético aplicado à biometria, assim como por ROEW \& AN DREW (1964) e EBERHART \& RUSSELL (1966), citados por esses autores, os quais incluiram a soma dos quadrados para ambien tes e interações genōtipos $x$ ambientes, bem como seu desdobramento. Ainda, segundo os dois últimos autores, uma boa estimativa de coeficientes de regressão pode ser obtida de poucos ambientes, desde que estes cubram as variações esperadas. Considerando que a distribuição de precipitação fluvial seja o fator ambiental mais importante, datas de plan- 
tio precoces e tardias podem ser frequentemente utilizadas para se obter um ambiente adicional para cada local. Do mesmo modo, densidades de plantas altas e baixas, níveis médios e altos de fertilizantes podem ser usados para aumentar o nú mero de ambientes possiveis de um número fixo de locais e, ao mesmo tempo, prover uma variação de condições ambientais.

VENCOVSKY \& GERALDI (1977) concluem que a ocor rência de interação genótipos $\mathrm{x}$ ambientes pode ser detectada estatisticamente, através da análise conjunta de experimentos repetidos em vários ambientes, e cujos tratamentos se jam constituidos de materiais genéticos. A detecção de significâncias para a interação não esclarece, contudo, as implicações que estas possam ter sobre o melhoramento, de forma que, estudos de detalhamento deste componente da variação são em geral necessários, sendo o da estabilidade um dos pro cedimentos.

O estudo da interação genótipo $\mathrm{x}$ ambiente tam bēm poderia ser enfocado conforme VENCOVSKY (1978) através do estudo da estabilidade de cultivares, baseando-se em estudos da variabilidade do caráter entre os ambientes para ca da cultivar, pois o método teria a grande vantagem de permitir uma particularização da interação para cada tratamen to, o que, evidentemente uma simples análise conjunta de ensaios não esclareceria.

o estudo da interação genótipos $x$ ambientes possibilita a identificação de cultivares mais adaptados a 
a determinadas regiões, onde as mesmas poderão expressar o seu potencial genético. Assim, estudos sobre a magnitude de tais interações podem ser úteis na regionalização de cultivares, objetivando indicar āreas onde as mesmas possam expressar o máximo que as condições ambientais particulares per mitam.

Em experimentação agrícola, como se sabe, é freqthente a necessidade de análise conjunta de grupos de experimentos. Isso ocorre quando se deseja inferir resultados para condições gerais de uma região. Nesse caso, uma série de experimentos é efetuada em locais representativos da região durante um número suficiente de anos que represente as alternativas de clima da região. Essa situação ocorre em programas de melhoramento de plantas cultivadas, quando o critério de lançamento de novas cultivares comerciais se baseia na análise do comportamento relativo das cultivares em diversos locais por um determinado periodo de anos (IGNAC ZAK \& SILVA, 1978).

No estudo da interação genótipos $x$ localidades em milho, RUSCHELL (1968), classificou os genótipos sob estudo em quatro grupos, a saber: populações, variedades sintēticas, hỉbridos e variedades locais. Os dados mostraram superioridade em rendimento cie grãos uos grupos das popu lações, das variedades sintēticas e dos hỉbridos em relação ao grupo das variedades locais. Observou também que o grupo dos hibridos apresentou uma maior estimativa da variancia de 
interação como localidades para produtividade, confirmando a relação do grau de adaptação com a heterogeneidade genētica da cultivar, e conferindo a capacidade adaptativa restrita dos genótipos de base genētica estreita.

LEMOS (1976), estimando o valor da interação genótipos $\mathrm{x}$ anos para diferentes grupos de cultivares de miTho, verificou que os caracteres: dias de florescimento, numero de espigas por planta, número de grãos por fileira e pe so de 50 grãos, apresentaram a mesma sequência em relação aos valores dos componentes de variação da interação tratamentos $\mathrm{x}$ anos.

SIIVA et alii (1963). fazendo estudos sobre interação, obtiveram dados que apresentaram valores significativos para a interação cultivares $x$ localidades. Contudo, das interações de cultivares $x$ anos, nenhuma delas apresen tou valor significativo, sendo que algumas interações cultivares $\mathrm{x}$ anos $\mathrm{x}$ locais foram significativas.

CORREIA DA SILVA (1981) manifesta que existem vários métodos de controle da interação genótipo x ambiente. De um modo geral, pode-se agrupar os métodos em duas linhas gerais de tratamento do problema. Uma delas se fundamenta na regionalização de locais e outra no estudo da estabilidade de cultivares. Dentro da primeira linha existem dois aspectos: um que se fundamenta principalmente nas caracteristicas ambientais, procurando-se ajustar as necessidades da cultura à disponibilidades ambientais existentes, especialmente no 
que se refere a clima e solos; o outro, parte das reações das cultivares quando expostas às diversas condições ambientais, procurando-se caracterizar regiões homogêneas, quanto ao com portamento relativo das cultivares.

\subsection{INTERACÃO GENOTI IPOS X AMBIENTES EM ALGODÃO}

MILLER et alii (1959) avaliaram a magnitude

dos componentes de variância da interação genótipos $\mathrm{x}$ ambien tes de 15 variedades de algodão (Gossypium hirsutum I.) em nove ambientes, durante três anos, na Carolina do Norte. Os autores encontraram que as interações genótipos x local x ano não foram significativas, concluindo que seria desnecessário a divisão da área estudada para fins de testes de rendimento, e que melhoramento para ambientes especificos deve ria ser praticável atē o limite em que importantes fatores ambientais estejam sob certo grau de controle previsível.

MILIER et alii (1962) analisaram alguns carac teres de 16 variedades de algodão (Gossypium hirsutum I.), em 11 localidades da Carolina do Norte durante três anos. Foram encontradas interações variedades $\mathrm{x}$ ano $\mathrm{e}$ variedades $\mathrm{x}$ ano $x$ local para rendimento de fibra, tenacidade e comprimento de fibra. Em todos os casos, as magnitudes destas interações foram pequenas quando comparadas com as fontes varietais de variação. Os autores salientam que o fato de que a intera- 
ção variedade $\mathrm{x}$ local $\mathrm{x}$ ano apresente significância, implica uma resposta diferencial dos caracteres em estudo sobre dife rentes condições ambientais. Isto significa que a influên cia daquelas condições não está associada com a influência do local isoladamente, mas foram resultados de combinações particulares de ambos.

ABOU-EL-FITTOUH et alii (1969a) analisaram $\circ$ comportamento de quatro variedades de algođão (Gossypium hir sutum, L.) em 39 locais durante dois anos, para caracterizar a natureza das interações genótipos $x$ ambientes, e identifi car algumas variáveis associadas com estas interações. Foram realizadas análises de variância para estimar as componentes entre os genótipos, interação genótipos $x$ ambientes e o erro experimental. Os resultados das análises para o caráter pro dução, mas foram relativamente menos importantes para os outros caracteres estudados, sendo a temperatura a variável que apresentou maior grau de associação com a interação genótipo $x$ ambiente.

ABOU-EL-FITTOUH et alii (1969b) compararam duas medidas de similaridade utilizando dados de produção provenientes de testes regionais de variedades de algodão (Gossypium hirsutum L.) da região do "Cotton Belt", nos anos 1960-1964 com propósitos de diminuir as interações genōtipos $x$ locais e estabelecer perspectivas para um novo zoneamento da região. As análises demonstraram que o coeficiente de distância è mais eficiente como medida de similaridade do que - coeficiente de correlação. 
BRIDGE et alii (1969) estimaram a magnitude das interações variedades $x$ ambientes utilizando oito variedades de algodão em três localidades, num perỉodo de três anos, no delta do Mississipi. A presença de uma interação variedade $x$ local $x$ ano para produção de fibra, porcentagem de fibra e peso do capulho, indicaram que as variedades mos traram respostas diferenciais quando cultivadas em ambientes diferentes. Com exceção da elongação e comprimento da fibra, as interações de segunda ordem para outros caracteres foram maiores que as interações de primeira ordem. A falta de uma interação significativa variedade x locais, ou variedade $\mathrm{x}$ ano para todos os caracteres medidos, indicaram que nem os locais, nem os anos tiveram qualquer efeito consisten te sobre as respostas diferenciais das variedades.

VERHALEN \& MURRAY (1969) testando interações genōtipo $\mathrm{x}$ ambiente envolvendo dez variedades de algodão em um local durante dois anos em oklahoma (EUA), encontraram um quadrado médio significativo da interação variedade $\mathrm{x}$ ano pa ra tenacidade da fibra, mas não para comprimento e resistência da fibra.

KOHEL (1969) avaliou o comportamento de nove linhagens parentais de algodão (Gossypium hirsutum L.) e suas progênies $F_{I}$ num sistema de cruzamentos dialélicos com pletos, em cinco ambientes durante dois anos, para os caracteres: produção, altura de plantas, precocidade, indice de sementes e porcentagem de fibra. Concluiu-se que não houve 
diferença entre a variabilidade dos pais com relação aos híbridos, embora os pais tivessem sido estáveis para os três dos cinco caracteres avaliados. O autor sugere, finalmente, que os organismos autofecundāveis podem corresponder a um es tado de transição, sem ter desenvolvido um mecanismo homeostático, tal como aquele encontrado em organismos de fecunda ção cruzada.

QUISENBERRY \& KOHEL (1971) estudaram oito caracteres fenotípicos de algodão (Gossyoium $\mathrm{sp}$ ) em cinco ambientes, para determinar os efeitos dos niveis de ploidia e de heterozigosidade sobre a estabilidade fenotipica de certas linhagens endogâmicas de algodão e seus hỉbridos. Os autores concluirram que o nivel de ploidia não afetou significa tivamente a estabilidade fenotipica dos oito caracteres $e$, a heterozigosidade intergenômica associada com a anfidiploidia, não conferiu vantagens às plantas pelo melhoramento de sua capacidade de adaptação às flutuações ambientais. Finalmente, os autores consideraram que as espécies de algodão que foram estudadas não possuiam sistemas homeostáticos associados com a homozigose ou heterozigose.

MCCALL et alii (1982) fizeram um estudo de es tajilidade para o caráter tenacidade de fibra em algodão (Gossypium hirsutum L.). As interações genótipo $x$ ambiente para este caráter foram significativas, porém, as magnitudes das componentes de variância das interações foram relativamente pequenas quando comparadas com as respectivas componen 
tes das cultivares. Foi concluido que estas interações são de minima importância na determinação destes caracteres, e que a classificação das cultivares nos diferentes ambientes foi praticamente a mesma. Portanto, a seleção em um ambiente garante o mesmo comportamento em outros.

SANTANA et alii (1983) realizaram estudos de produção e adaptação de algodão herbãceo (Gossypium hirsutum L.) submetidos a vinte diferentes ambientes das regiões Norte e Nordeste do Brasil durante dois anos. Com base nos resultados obtidos, os autores concluiram que houve uma variação de ambientes, os quais influenciaram no comportamento das cultivares no que se refere à produção e capacidade adaptatí va.

OMRAM et alii (1983) avaliaram o comportamen to produtivo de seis novas variedades em relação a três variedades comerciais de algodão (Gossypium hirsutum L.) em três localidades durante três anos. A análise dos resultados mostrou que existe uma resposta diferencial das variedades sob condições ambientais diferentes. Essas condições não es tão associadas com a influência do local e do ano sozinhos, mas são resultados de combinações particulares de ambos. As diferenças entre localidades foram mais pronunciadas do que aquelas entre anos, e a variância da interação localidade $\mathrm{x}$ variedade foi mais importante do que a variância da interação variedade $\mathrm{x}$ ano. 
SING \& GILL (1984) estudaram a diversidade ge nética de 62 variedades de algodão herbáceo (Gossypium hirsu tum L.) em quatro ambientes, através da estatistica $D^{2}$ generalizada de Mahalanobis (1936) e agrupamento pelo método de Tocher (RAO, 1952). Todas as variedades foram agrupadas em doze blocos em cada ambiente, com exceção de um ambiente com dez blocos. Os resultados demonstraram que os oito caracte res considerados nos quatro ambientes foram altamente significativos, demonstrando que a diversidade genética não estava diretamente relacionada com a diversidade geográfica. Tam bēm houve variação no agrupamento em diferentes ambientes, presumivelmente devido a respostas diferenciais dos diferen tes caracteres nos ambientes, mostrando portanto, que o padrão de agrupamento em um ambiente pode não ser aplicável em outro ambiente.

\subsection{Estabilidade DE CULTIVARES}

o termo "estabilidade de produção" de varieda des de plantas cultivadas tem sido definido sob formas diferentes. Usualmente, uma variedade é considerada estável se apresentar aperas pequenas variações no seu comportamento ge ral, quando desenvolvida sob condições ambientais diversas. Segundo este conceito, não se considera importante a potencialidade de ambientes em proporcionar altas ou baixas produ 
tividades, isto é, a variedade estável tem mais ou menos o mesmo rendimento, quer os ambientes sejam favoráveis ou desfavorāveis. Este tipo de variedade é de grande utilidade pa ra os pequenos agricultores, que carecem de recursos para a aplicação de nĩveis adequados de tecnologia e portanto, devem adotar variedades pouco sensíveis às alterações ambientais (OLIVEIRA, 1976 ).

Para eliminar o efeito ambiental e se trabalhar o máximo possível com o potencial genético do material, foi desenvolvida uma série de técnicas de condução em todas as fases do melhoramento, para se ter maior segurança no desempenho do trabalho. Quando as diferenças entre os genótipos são estreitas, lança-se mão dos recursos de experimenta ção em delineamentos estatisticos que permitem o isolamento da interação genōtipo x ambiente (PEIXOTO et alii, 1985).

o método mais antigo usado para se avaliar a estabilidade consiste em uma análise de variância conjunta de uma série de experimentos desenvolvidos em vários locais e em vārios anos. Atravēs desse procedimento estudou-se não apenas os efeitos isolados de variedades, locais e anos, mas tambēm as interações variedades $x$ locais, variedades $x$ anos, locais $\mathrm{x}$ anos e variedades $\mathrm{x}$ locais $\mathrm{x}$ anos, considerações que proporcionam estimativas das magnitudes de suas variāncias.

FINLAY \& WILKINSON (1963) consideram adequada a metodologia de análise de grupos de experimentos, mas 
pouco sensivel para indicar a existência de interações com ambientes. Consideram essa metodologia como uma medida bási ca de adaptabilidade, porém, seu uso torna-se difícil quando se avalia um grande número de genōtipos.

YATES \& COCHRAN (1938) sugerem a decomposição da interação cultivares $x$ ambientes. Para cada cultivar determina-se a regressão linear da produtividade em relação à média do caráter expressa por todas as cultivares em cada am biente. Desta forma, uma equação de regressão è apresentada para cada cultivar. Essa equação, representada em um grá fico de eixos cartesianos, mostra o comportamento individual de cada cultivar e o efeito dos diferentes ambientes.

PLAISTED \& PETERSON (1959) apresentaram um mé todo para caracterizar a estabilidade da performance de produção. No caso da anālise de resultados de um ano, o primeiro passo è uma análise conjunta de todas as variedades em todos os locais. Se a interação variedades x locais é significativa, efetua-se a anālise de variância conjunta de todos os anos para cada combinação de variedades tomadas duas a duas. Para $\underline{m}$ variedades serão necessārias $m(m-1) / 2$ anālises. As análises conjuntas fornecem uma estimativa de $\sigma_{\mathrm{V} l}^{2}$ (componente de variância da interação variedades x locais) pạ ra cada par de variedades. Calcula-se então, a média aritmé tica das estimativas de $\sigma_{V I}^{2}$ para cada variedade. A variedade que corresponde ao menor valor médio é a que menos contri bui para as interações variedades $x$ locais e, assim, é consi derada a mais estável no teste. 
WRICKE (1965) define um parâmetro de estabili dade que ele denomina de "ecovalência" (valência ecológica). A ecovalência é uma medida de avaliação das oscilações de rendimento sob variadas condições de ambientes. A soma de quadrados da interação variedades $\mathrm{x}$ ambientes é dividida nas partes atribuíveis às variedades isoladas.

O mesmo autor menciona que, freqtientemente, tem surgido a suposição de que variedades mais promissoras mostram, em média, oscilações mais acentuadas de rendimento do que as menos promissoras. Entretanto, ele não encontrou nenhuma correlação entre rendimento e ecovalência em variedes de cebola.

Se de fato houvesse uma correlação negativa entre bom rendimento e pequena ecovalência, uma variedade com alto rendimento poderia estar na categoria das que no decorrer do trabalho de melhoramento, atingiram tal nivel que se tornam inadequadas para melhoramentos posteriores.

O método de FINLAY \& WILKINSON (1963) para com parar a performance de um conjunto de variedades em vários ambientes se baseia em uma análise de regressão simples. As duas variāveis consideradas para a estimação do coeficiente de regressão são o incide de ambiente (variável independen tel e a produtividade individual média de cada var-edade em cada ambiente (variável dependente).

Para a determinação da estabilidade desse método os Indices importantes são o coeficiente de regressão e a produção média da variedade sobre todos os ambientes. 
Previamente à anālise, as produtividades são transformadas em uma escala logarítmica que, segundo FINLAY 7 wilkinson (1963), induzem a um alto grau de linearidade na regressão. O uso de escala logarítmica também conduziu a um razoável grau de homogeneidade da variância do erro.

Baseando-se no coeficiente de regressão, FINLAY \& WILKINSON (1963) caracterizam vários tipos de adaptação de variedades. Variedades com um baixo coeficiente de regressão mostram um alto grau de estabilidade fenotípica. Neste caso, as produtividades em todos os ambientes são as mesmas. A estabilidade absoluta é expressa por $b=0$.

As variedades fenotipicamente instáveis estão associadas a altos valores para os coeficientes de regressão. Valores negativos, ainda que eventualmente possam ocor rer, não são de interesse do pesquisador. Variedades com coeficiente de regressão próximo de 1,0 têm estabilidade média sobre todos os ambientes.

EBERHART \& RUSSELI (1966), estudaram parâmetros de estabilidade para comparação de variedades de milho (Zea mays L.) e propõe um modelo nos mesmos moldes daquele sugerido por YATES \& COCHRAN (1938) e semelhante ao de FIN LAY \& WILKINSON (1963).

o referido método considera a regressão de cạ da variedade do experimento em relação a um só indice de ambiente, tal como foi definido no método de FINLAY \& WILKINSON (1963). Os parâmetros de estabilidade para cada variedade 
são o coeficiente de regressão e uma medida dos desvios de regressão.

Os mesmos autores, em desacordo com FINLAY \& WILKINSON (1963), consideram que seria desejável um indice ambiental independente das variáveis experimentais e obtidos de fatores estranhos aos dados, tais como chuva, temperatura e fertilidade do solo. Não usam este procedimento devido ao fato de não se ter conhecimentos da relação entre tais fatores e a produtividade, o que impede a estimação de tais indices.

Ainda esses aulores mencionam que análises de vários conjuntos de dados em ensaios de produção de milho, na Universidade do Estado de Iowa (Estados Unidos), têm indicado que híbridos com um coeficiente menor que 1,0 geralmente têm produtividades médias abaixo da produtividade média geral.

Coeficientes de regressão acima de 1,0 indi cam uma elevada sensibilidade à mudanças de ambiente (baixa estabilidade), e maior especificidade na adaptação a ambien tes de alta produtividade. Coeficientes de regressão abaixo de 1,0 indicam uma baixa sensibilidade à troca de ambientes (alta estabilidade), e maior especificidade na adaptação a ambientes de baixa produtividade.

Em resumo, o coeficiente de regressão próximo de 1,0 indica estabilidade média. Quando isso é associado com uma alta média de produtividade, a variedade tem capacidade 
geral de adaptação; quando associado com baixa média de produtividade, a variedade é pouco adaptada a todos os ambientes.

o melhorista de plantas, normalmente deseja variedades que se comportem acima da média geral em qualquer ambiente. Logo, deseja variedades de médias altas, coeficiente de regressão unitário e desvios da regressão tão pequenos quanto possiveis. Assim, para EBERHART \& RUSSELL (1966). variedade estável é aquela a que correspondem coeficiente de regressão 1,0 e desvio de regressão zero.

TAI (1971) descreve um parâmetro estatistico apropriado para estabilidade. O método de TAI (1971) é semelhante ao de EBERHART \& RUSSELL (1966), em que se tenta determinar a resposta linear da variedade para os efeitos ambientais. A diferença está nos parâmetros e envolve uma extensão do modelo matemático convencional para a análise de variância; estima o potencial genético da variedade para estabilização na performance, quando variam os ambientes. Os parâmetros são definidos como $\alpha_{i} e \lambda_{i}$, sendo $\alpha_{i}$ estimado pela covariância entre os efeitos da interação variedades $x$ am bientes, dividida pela variância dos efeitos ambientais, e $\lambda_{i}$ estimado pela razão entre a variância dos desvios da resposta linear e a variância do erro associada com os efeitos da interação variedades $x$ ambientes mais a unidade.

Uma variedade perfeitamente estável não mudará sua performance de ambiente para ambiente. Isto equivale a afirmar que para esta $\alpha=-1$ e $\lambda=1$. 
TAI (1971) salienta que uma variedade perfeitamente estável provavelmente não existirā. Assim, segundo este autor, o melhorista ficará satisfeito com a obtenção de niveis médios de estabilidade. Os valores $(\alpha=0, \lambda=1)$ são referidos como estabilidade média, e os valores $(\alpha=-1$, $\lambda=1)$ como perfeita estabilidade.

Estudos desenvolvidos por VERMA et alii (1978) propõem uma técnica alternativa, que consiste no ajustamento separado de dois segmentos de reta, de forma a discriminar os genótipos que tenham uma resposta constante em ambientes negativos, e que apresentam maiores respostas em ambientes favorāveis. Este é o genótipo ideal procurado pelo melhoris ta que se pode detectar por esta técnica de análise da inte ração. Associando os métodos até então citados, SILVA \& BAR RETO (1985), propõe a utilização de regressão múltipla, que consiste no ajuste único dos dois segmentos de reta, sugeridos por VERMA et alii (1978).

\subsection{Agrupamento de ambientes}

O processo de regionalização visa o agrupamen co de locais de uma área geográfica em subáreas de modo a se obter uma redução da magnitude das interações cultivares $x$ locais. Assim, parece lógico que se procure dividir a área em subāreas, tendo como base as caracteristicas de temperatu 
ra, precipitação e tipos de solos, de modo a minimizar a interação cultivares x locais (CORREIA DA SILVA, 1981).

VENCOVSKY (1978) também concorda com a realização de zoneamento ecológico para estudar a interação genótipos $\mathrm{x}$ ambientes. Para isso, tem-se necessidade de conduzir experimentos em locais e anos representativos, procurando-se descobrir grupos de localidades dentro dos quais a com ponente de interação $\sigma_{\text {ta }}^{2}$ (tratamentos $x$ ambientes) é minimizada, podendo ser maximizada entre agrupamentos. Estudos des sa natureza foram feitos por ROSITO (1974) em trigo, para o estado do Rio Grande do Sul, onde o autor constatou uma razoável compatibilidade entre a regionalização existente e a estabelecida pelo estudo realizado, considerando a interação genōtipos $x$ ambientes.

MOTA et alii (1974) apresenta uma proposta de regionalização agroclimātica do Rio Grande do sul para vārias culturas, utilizando como critērio básico as aptidões climáticas das culturas, definidas com base em suas exigências e cotejadas com as disponibilidades climāticas das regiões. O método considera apenas os fatores climáticos, sen do tal restrição justificada, segundo os autores, pela incapacidade desses fatores serem controlados em uma explotação agiicola, womo podem sê-lo os caracteres edafológicos.

SILVA et alii (1963) estudando a interação de cultivares de milho em localidades do Estado de são paulo e, considerando o aspecto da regionalização de cultivares, cons 
tatam que a influência de solos mostrou-se mais importante do que o efeito das variações climáticas de um para outro ano, com relação à variabilidade de produção.

HORNER \& FREY (1957) propõem a subdivisão do Estado de Iowa em regiões homogêneas que possibilita uma ade quada recomendação regional de variedades de aveia, utilizan do um procedimento para a redução da interação cultivares $\mathrm{x}$ locais dentro de cada região. Eles sugerem distintos agrupa mentos de locais para cada uma das subdivisões do Estado em $2,3,4$ e 5 regiões, utilizando resultados de experimentos efetuados em nove locais durante cinco anos, com poucas varieda des comuns a todos os anos. Para cada uma dessas quatro clas ses de subdivisões é obtido o quadrado médio da interação cul tivares $\mathrm{x}$ locais dentro da região, conforme os agrupamentos resultantes das subdivisões mais coerentes do ponto de vista de proximidade geográfica. O melhor agrupamento de locais para cada uma das regionalizações em 2, 3, 4 e 5 regiões reduziu ○ quadrado médio de $11 \% ; 21 \% ; 30 \%$ e 40\%, respectivamen te, em relação ao quadrado médio da interação, abrangendo o estado todo.

Entre os processos multivariados, ABOU-EL-FITTOUH et alii (1969b), utilizam análise de conglomeração ("cluster analysis": para ciassificação de locais. Os dados utili zados foram resultados de experimentos de competição de cultivares de algodão do cotton Belt durante dois ciclos, com o objetivo de diminuir a interação cultivares $x$ locais. Traba- 
Iharam inicialmente com uma matriz de estimativas dos efeitos interação cultivares $x$ locais para cada um dos dois ciclos da cultura de algodão em estudo. A partir de cada uma dessas matrizes obtiveram duas medidas de similaridades entre todos os possiveis pares de locais. Estas medidas de si milaridade são um coeficiente de distância e um coeficiente de correlação. A partir desses, os locais com tipos de interação mais similares são agrupados em sucessivos estāgios, até a formação de um único grupo.

Os autores concluem que a medida de similaridade que se mostra mais adequada é o coeficiente de distância, utilizando como critério de escolha entre as duas medidas a soma de quadrados da interação variedades x local dentro de grupos de locais para equivalentes estágios do proces so de conglomeração.

BYTH et alii (1976) utilizam procedimento de anālise de conglomeração e ordenação para análise de um grupo de experimentos internacionais do Centro Internacional de Melhoramento de Milho e Trigo (CIMMYT). Os dados correspon dendem à produção de 49 cultivares de trigo, escolhidos entre os mais cultivados no mundo, obtidos de experimentos efetuados em 63 locais situados ein extensa área de cultivo no período 1967/1968. O método É ampliado para fazer uma du pla classificação: de locais e de cultivares.

CAMPBELL \& LAFEBER (1977). adotaram o método de conglomeração para agrupar e estudar as similaridades de 
nove locais de experimentos de trigo no leste dos Estados Uni dos, a partir da produção média de onze cultivares em três anos. Utilizam como medida de similaridade o coeficiente de correlação entre as produções médias dos três anos de todos os possiveis pares de locais.

$$
\text { CORDEIRO (1978) aplica o método de conglomera }
$$
ção, tal como utilizado por ABOU-EL-EITTOUH et alii (1969b). As similaridades são um coeficiente de distância. o autor efetua anālises preliminares para comparação de resultados dos métodos de máxima distância, centróide e ligação média, métodos que aglomeram as entidades a serem classificadas uma a uma, e adota o método da ligação média por se mostrar mais estável e oferecer melhores recursos para interpretação.

SEIF et alii (1979) apresentam um procedimento multivariado para classificar locais, utilizando análise canônica. Os autores trabalham com nove cultivares de trigo em onze locais da região tritícola da Austrália, e sugerem a subdivisão da mesma em duas sub-regiões. 


\title{
3. MATERIAL E MÉTODOS
}

\author{
3.1. Material
}

Foram utilizados dados de rendimento em $\mathrm{kg} /$ $20 \mathrm{~m}^{2}$ de 10 yenōtipos de algodão, provenientes de ensaios regionais correspondentes aos anos agrícolas 1985/86 e 1986/ 87. Estes genōtipos incluem variedades e linhagens promisso ras, materiais estes selecionados no Instituto Agronômico Nạ cional (I.A.N.), centro experimental ligado ao Ministério de Agricultura e Pecuária do Paraguai.

Os experimentos foram conduzidos, através do Programa Nacional de Algodão e o Projeto de Investigação e Ex perimentação Algodoeira, objetivando avaliar o potencial pro dutivo, precocidade e caracteristicas tecnológicas da fibra de variedades e linhagens promissoras, recentemente seleciona das. Os tratamentos foram comparados com a variedade Reba P-279, material utilizado em todos os experimentos cons tes temunha, por ser o único genótipo de ampla adaptação, recomendado pelo Ministério da Agricultura para cultivo.

Os experimentos foram instalados em seis loca 
lidades: Pirareta, Ybycui, Caaguazú, Caazapa, Coronel Bogado e concepción, os quais são considerados como as regiões mais representativas das zonas produtoras de algodão do país e abrangem os seguintes Estados: Paraguari, Caaguazú, Caazapa, Itapua e Concepción. A Figura 1 apresenta a localização dos ensaios nas diferentes regiões produtoras de algodão (Gossypium sp).

Na Tabela 1 são apresentados os genótipos uti lizados como tratamentos no ano $1985 / 86$.

Adotou-se o delineamento experimental de blocos ao acaso com três tratamentos e oito repetições. As par celas experimentais constituiram-se de três fileiras de 20 metros de comprimento, espaçados de um metro, sendo a ārea útil constituída pela fileira central, perfazendo $20 \mathrm{~m}^{2}$. 0 espaçamento entre plantas dentro das fileiras foi de 0,25 me tros.

Efetuou-se a semeadura manualmente, colocandose cinco a sete sementes por cova à profundidade de três centimetros, realizando-se desbaste após 30 dias deixando duas plantas por cova, uniformizando a população em 80.000 plantas por hectare para todos os tratamentos em todos os locais. Os experimentos foram instalados no mês de outubro, época recomendada pela pesquisa para a cultura do algodão.

A adubação de base foi feita para todos os tratamentos em todos os locais, utilizando-se $18 \mathrm{~kg} / \mathrm{ha}$ de $\mathrm{ni}$ trogênio, $40 \mathrm{~kg} / \mathrm{ha}$ de fósforo na forma de fosfato diamônico e $50 \mathrm{~kg} / \mathrm{ha}$ de potāssio, na forma de cloreto de potássio. Por 


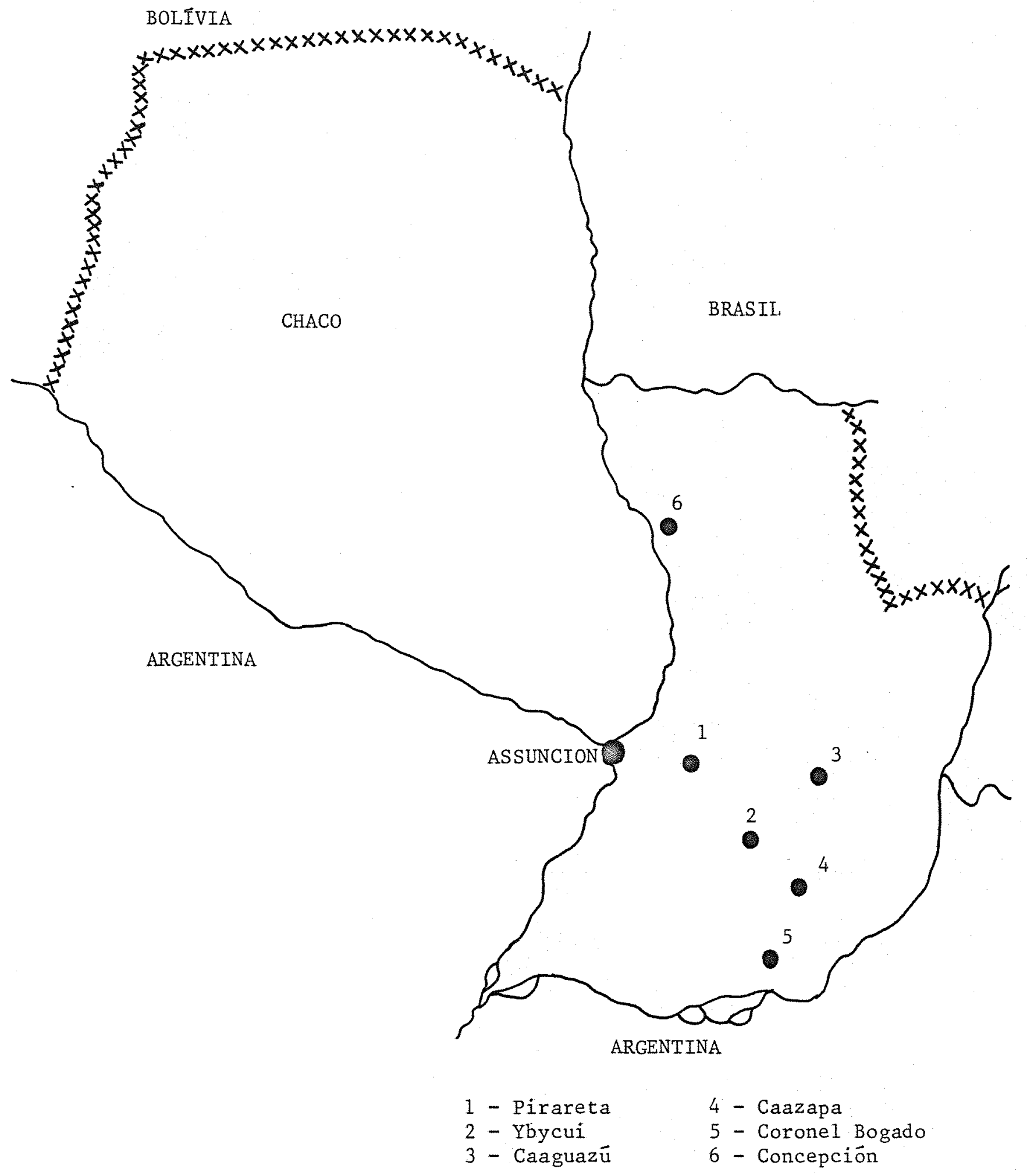

Figura 1. Distribuição dos ensaios regionais nos diferentes locais da região Oriental do Paraguai. Anos agrícolas 1985/86 e 1986/87. 
ocasião do florescimento realizou-se adubação de cobertura, utilizando-se $22,5 \mathrm{~kg} / \mathrm{ha}$ de nitrogênio na forma de uréia, com pletando-se assim a formulação recomendada de 40-40-50.

Tabela 1. Genótipos utilizados como tratamentos no experimen to do ano $1985 / 86$.

Genōtipos Origem

Variedade

REBA $\mathrm{P}-279$ (testemunha

Paraguai

Linhagens promissoras

$\mathrm{SP}-510 \times \mathrm{P}-279-100$

Paraguai

$\mathrm{SP}-510 \times \mathrm{P}-279-22$

Paraguai

Da mesma forma, na Tabela 2 são apresentados os genótipos utilizados como tratamentos no experimento do ano $1986 / 87$.

o delineamento experimental utilizado foi o látice simples $3 \times 3$ com quatro repetições, porém as anālises estatísticas foram realizadas em blocos ao acaso devido ao pe queno número de tratamentos e à não eficiência do delineamento em látice. A parcela experimental e os tratos culturais foram similares no experimento do ano 1985/86. 
Tabela 2. Genótipos utilizados como tratamentos no experimen to do ano agrícola $1986 / 87$.

\begin{tabular}{|c|c|}
\hline Genótipos & Origem \\
\hline \multicolumn{2}{|l|}{ Variedades } \\
\hline REBA P-279 (testemunha) & Paraguai \\
\hline Guazuncho & Argentina \\
\hline \multicolumn{2}{|l|}{ Linhagens promissoras } \\
\hline$S P-510 \times P-279-100$ & Paraguai \\
\hline$S P-510 \times P-279-28 / 39$ & Paraguai \\
\hline$S P-510 \times P-279-29 / 43$ & Paraguai \\
\hline$S P-510 \times p-279-32$ & Faraguai \\
\hline$S P-510 \times P-279-38 / 41$ & Paraguai \\
\hline $\mathrm{sP}-510 \times \mathrm{P}-279-40 / 42$ & Paraguai \\
\hline TAMCOT SP $21-S$ & USA \\
\hline
\end{tabular}

\subsection{Metodologia}

\subsubsection{Anālise da variância}

Procedeu-se preliminarmente, à análise indi vidual dos experimentos para cada local e ano, a fim de avaliar a significância do quadrado médio entre tratamento, e se determinar as estimativas de variância do erro experimental, segundo o modelo matemático: 


$$
\mathrm{y}_{i j}=\mu+v_{i}+b_{j}+e_{i j}
$$

onde:

$$
\begin{aligned}
& \mathrm{Y}_{i j}=\text { rendimento do tratamento } i \text { na repetição } j ; \\
& \mu \quad=\text { média geral; } \\
& \mathrm{v}_{i}=\text { efeito do tratamento } i ; \\
& \mathrm{b}_{j}=\text { efeito do bloco } j ; \\
& e_{i j}=\text { efeito do erro experimental. }
\end{aligned}
$$

Todas as anālises de variância foram feitas de acordo com um modelo fixo. Dessa forma, os resultados serão válidos para os genótipos e as localidades consideradas. Com base num modelo fixo, todas as fontes de variação foram testadas com o quadrado médio residual (STEEL \& TORRIE, 1960). O quadro da análise da variância para cada local e ano são apresentados na Tabela 3 .

Tabela 3. Esquema da anālise individual da variância.

\begin{tabular}{lccc}
\hline Fontes de variação & GL & QM & $F$ \\
\hline Blocos & $r-1$ & $Q_{B}$ & \\
Genótipos & $t-1$ & $Q_{T}$ & $Q_{T} / Q_{R}$ \\
Resíduo & $(r-1)(t-1)$ & $Q_{R}$ & \\
\hline Total & $(r . t)-1$ & & \\
\hline
\end{tabular}

onde:

$$
\begin{aligned}
& r=\text { número de repetições } \\
& t=\text { número de tratamentos }
\end{aligned}
$$


Os testes de homogeneidade das variâncias dos erros experimentais entre locais foram obtidos pelo teste de F máximo e as médias dos tratamentos foram comparadas pelo teste de Tukey.

No caso dos experimentos realizados em 1985/86, que apresentaram heterogeneidade dos quadrados mëdios residuais, para fins de análise conjunta utilizou-se a metodologia de Cochran (1954), conforme PIMENTEL GOMES (1985).

Após testar a homogeneidade das variâncias, e a fim de verificar a ocorrência de comportamento diferencial dos genótipos nas diferentes localidades, foram feitas as anā lises conjuntas dos experimentos para cada ano. Para esse fim utilizaram-se as médias dos tratamentos correspondentes aos dois anos de teste, de acordo com o seguinte modelo matemático:

$$
Y_{i j k}=\mu+v_{i}+a_{k}+(v a)_{i k}+b_{j k}+\bar{e}_{i j k}
$$

onde:

$$
\begin{aligned}
\mathrm{Y}_{i j k}= & \text { observação média do tratamento } i, \text { na repetição } \\
& j \text { do ambiente } \mathrm{k} ; \\
\mu & \text { média geral; } \\
\mathrm{v}_{i}= & \text { efeito do tratamento } i ; \\
a_{k}= & \text { efeito do local } \mathrm{k} ; \\
(\mathrm{va})_{i k}= & \text { efeito da interação do tratamento } i \text { com o local } \mathrm{k} ; \\
\mathrm{b}_{j k}= & \text { efeito da repetição } j \text { no local } \mathrm{k} ; \\
\bar{e}_{i j k}= & \text { erro experimental associado à média }{ }_{i j k} .
\end{aligned}
$$

As fontes de variação das anālises conjuntas foram testadas com o quadrado médio ponderado do erro experimental, obtidos atravēs da somatória das somas de quadra- 
dos do erro experimental de cada local e ano, o qual é repre sentado esquematicamente na Tabela 4.

Tabela 4. Análise conjunta da variância.

\begin{tabular}{lccc}
\hline Fontes de variação & GL & $\mathrm{QM}$ & $\mathrm{F}$ \\
\hline Blocos & - & - & - \\
Genótipos (T) & $t-1$ & $\mathrm{Q}_{\mathrm{T}}$ & $\mathrm{Q}_{\mathrm{T}} / \mathrm{Q}_{\mathrm{R}}$ \\
Locais (L) & $I-1$ & $\mathrm{Q}_{\mathrm{L}}$ & - \\
Gen. x Loc. (TxL) & $(\mathrm{t}-\mathrm{I})(I-I)$ & $\mathrm{Q}_{\mathrm{TL}}$ & $\mathrm{Q}_{\mathrm{TL}} / \mathrm{Q}_{\mathrm{R}}$ \\
Resíduo médio & $\sum_{\mathrm{k}}$ & & \\
\hline
\end{tabular}

Total

onde:

$$
\begin{aligned}
t= & \text { número de genótipos; } \\
I= & \text { nümero de locais; } \\
r= & \text { nümero de repetições; } \\
\eta_{k}= & \text { número de graus de liberdade do residuo da } \\
& \text { análise do local } \mathrm{k} .
\end{aligned}
$$

\subsubsection{Anālise de estabilidade}

o estudo da estabilidacie fenotípica para o ca rāter produtividade dos genótipos testacus nos seis ambientes, foi feito dentro de cada ano, segundo a metodologia de EBERHART \& RUSSEL (1966). O método se fundamenta essencialmente em dois parâmetros principais, ou seja, o coeficiente de regressão 
(b) e a variância dos desvios de regressão $\left(\sigma_{\mathrm{d}}^{2}\right)$.

Quando o coeficiente de regressão linear de um genōtipo è superior à unidade (b > 1), significa que a mesma responde positivamente às melhorias ambientais, no entanto, em condições desfavoráveis este comportamento pode ser bastante prejudicado. Por outro lado, quando o coeficiente de regressão linear é inferior à unidade $(b<1)$, esta não responde satisfatoriamente às melhorias ambientais, mas também não sofre prejuizos sérios em condições desfavorāveis.

A variância dos desvios da regressão quando baixa, indica que um genōtipo em ambientes semelhantes de ve apresentar comportamentos semelhantes. No entanto, quando a variāncia dos desvios da regressão for alta, o genótị po não deve apresentar o mesmo comportamento em ambientes se melhantes. Portanto, este parâmetro è de fundamental importância na avaliação da estabilidade de um cultivar. E impor tante salientar que tanto os valores de $\underline{b}$ como os da variância dos desvios da regressão só serão de utilidade nas recomendações de genōtipos quando estiverem associadas à prodū tividade média superior das respectivas cultivares.

Os dados utilizados para análise de estabilidade foram as médias dos tratamentos ccrresponduntes aos anos $1985 / 86$ e 1986/87, por apresentarem significância à interação genótipo $\mathrm{x}$ ambiente. o modelo do quadro de análise de variância, segundo o modelo de EBERHART \& RUSSELL (1966) è esquematizado na Tabela 5 . 
Tabela 5. Esquema da anālise da variância segundo método de EBERHART \& RUSSELL (1966).

\begin{tabular}{|c|c|c|}
\hline Fontes de variação & GL & $\mathrm{QM}$ \\
\hline Genōtipos (T) & $t-1$ & $Q^{M T}$ \\
\hline Locais (L) & $\ell-1$ & $\mathrm{QM}_{\mathrm{L}}$ \\
\hline Interação Genot. x Locais (TxI) & $(t-1(\ell-1)$ & $\mathrm{QM}_{\mathrm{TL}}$ \\
\hline Locais dentro de genötipos(TxL) & $t(\ell-1)$ & \\
\hline Regressão Iinear & 1 & \\
\hline Interação TxL (linear) & $t-1$ & $\mathrm{QM}_{\mathrm{TL}}$ (Iinear) \\
\hline Desvios combinados & $(\ell-2)$ & QM desvios \\
\hline genōtipo 1 & $\ell-2$ & \\
\hline genótipo 2 & $\ell-2$ & \\
\hline$\ldots$. & $\cdots \cdots$ & \\
\hline genōtipo (T) & $l-2$ & \\
\hline Erro médio Ponderado & $\ell(t-1)(r-1)$ & $\mathrm{QM}_{\text {Erro }}$ \\
\hline Total & $t \ell-1$ & \\
\hline
\end{tabular}


o modelo de regressão adotado foi:

$$
\bar{Y}_{i k}=\mu_{i}+\beta_{i} I_{k}+\delta_{i k}
$$

onde: $\bar{y}_{i k}$ é a média das repetições do genōtipo i no local k; $\mu_{i} \circ$ efeito do i-ésimo genōtipo nos locais; $\beta_{i} \bar{e}$ o coe ficiente de regressão que mede a resposta do i-ésimo genótipo nos diversos locais; $\delta_{i k} e ́$ o desvio da regres são do i-ésimo genótipo no k-ésimo local, e $I_{k}$ é o índice ambiental obtido como a média de todos os genóti pos no k-ésimo local menos a média geral.

o primeiro parâmetro de estabilidade é o coeficiente de regressão, estimado da maneira usual:

$$
b_{i}=\frac{\sum_{i k} \bar{Y}_{i k} I_{k}}{\sum_{k} I_{k}^{2}}
$$

o outro parâmetro de estabilidade considerado é o desvio da regressão, obtido da seguinte forma:

$$
\mathrm{s}_{\mathrm{d}_{\mathrm{i}}}^{2}=\frac{\sum_{\mathrm{k}} \delta_{\mathrm{ik}}^{2}}{l-2}-\frac{\mathrm{QM}_{\mathrm{e}}}{\mathrm{r}},
$$

As hipóteses, $h_{0}: \beta_{i}=1,(i=1, \ldots, t)$ foram testadas pelo teste $t$ :

$$
t=\frac{b_{i}-1}{\operatorname{Var}\left(b_{i}\right)}
$$

Os desvios da regressão para cada variedade foram testados pelo teste $\mathrm{F}$ :

$$
F=\frac{\sum_{k}^{\sum} \delta_{i k}^{2} /(t-2)}{Q M_{e} / r}
$$




\subsubsection{Classificação de ambientes}

\subsubsection{Similaridade}

A possibilidade de se medir a similaridade en tre uma coleção de entidades e classificā-las em grupos, a partir de um conjunto de critérios, tem sido estudado por mui tos pesquisadores.

vários mētodos têm sido propostos para a avaliação numérica de afinidades ou similaridades entre entidą des, e a ordenação destes em grupos a partir de suas afinidades. SOKAL \& SNEATH (1963) apresentam detalhada exposição de todas as formas de análises usadas em taxonomia numérica para resolver problemas de similaridade e classificação de en tidades.

Neste estudo, são utilizados mētodos de classificação numērica, para identificar se existem entre os 1ocais estudados padrões de interações similares, em relação aos genōtipos utilizados. Para uma anālise objetiva e uma visão conjunta das similaridades, a classificação dos locais foi efetuada dentro de cada ano.

Os valores do efeito da interação genótipos $x$ locais, cujo elemento genérico (vâ) ${ }_{\text {ik }}$ quantifica a magnitú de da interação relativa ao i-ésimo genótipo no k-ésimo local, são representados da seguinte forma: 
42.

$$
\text { (va) }_{i k}=\bar{Y}_{i k}-\bar{Y}_{i \cdot}-\bar{Y}_{. k}+\bar{Y}_{.}
$$

Para o caráter estudado temos:

$Y_{i k}=$ mëdia do i-ésimo tratamento no k-ésimo local;

$\bar{Y}_{i .}=$ média geral do i-ésimo tratamento;

$\overline{\mathrm{Y}}_{. \mathrm{k}}=$ média geral do $k$-ésimo local;

$\bar{Y}_{. .}=$média geral dos $t$ tratamentos nos 1 locais.

Para medir a similaridade entre os locais, cada local é representado por um vetor de valores da interação genōtipos x. local, constituindo o conjunto desses vetores as matrizes do efeito da interação referenciado no paràgrafo anterior.

A similaridade entre os locais foi determinada atravēs da "Distância Euclidiana Média", definida como a distância média entre dois pontos $\mathrm{kk}^{\prime}$ em um espaço de $\underline{c}$ dimensões, e expressada no seguinte modelo:

$$
\begin{aligned}
& \text { para o par de locais } k \text { e k' } \\
& \mathrm{d}_{\mathrm{kk}^{\prime}}=\Delta_{\mathrm{kk}^{\prime}} / \sqrt{t} \\
& \Delta_{k k^{\prime}}=\left\{\sum_{i=1}^{t}\left[\begin{array}{ll|}
(v \bar{a})_{i k}-(v \bar{a})_{i k} & \\
&
\end{array}\right\} 1 / 2\right. \\
& i=1,2,3, \ldots, t: \text { no de tratamentos. }
\end{aligned}
$$


Esta medida $\Delta_{k \mathrm{k}}$, foi primeiramente definida para classificação numérica por SOKAL (1961). Desde que $\mathrm{k}_{\mathrm{kk}}$

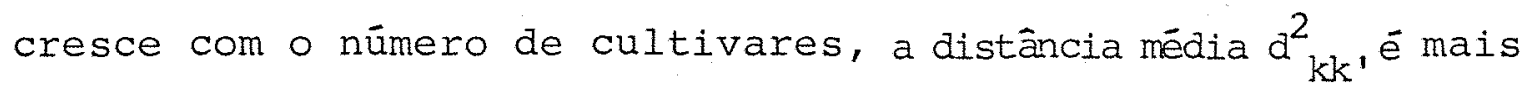
comumente utilizada (SOKAL \& SNEATH, 1963).

A utilização da Distância Euclidiana Média no presente estudo justifica-se pelo fato de estar estreitamente relacionada com a soma de quadrados da interação genōtipo $x$ local. Mostra-se que, $\frac{t}{2} \mathrm{~d}_{\mathrm{kk}}^{2}$ é a soma de quadrados da in teração dentro de uma região formada pela combinação dos locais $\mathrm{k}$ e $\mathrm{k}^{\prime}$. Estas distâncias são computadas para todos os possiveis pares de locais, e para cada uma das matrizes da interação cultivares $x$ locais correspondentes às anālises de interesse.

\section{2 .3 .2 . Agrupamento}

Para o agrupamento de locais em "cluster", ado tou-se a metodologia de K.D. Tocher (RAO, 1952). o método consiste em agrupar os locais, tomando como base as medidas de similari de determinadas através da "Distância Euclidiana Média", sobre a qual é identificado o par de locais mais próximo, ou seja, aqueles que apresentaram menores valores de $\mathrm{d}_{k k^{\prime}}^{2}$ Estes locais constituiram o primeiro grupo. A partir desses valores serão avaliados a possibilidade de inclusão du novos locais dentro do grupo, adotando-se o critério anteriormente citado. o processo continua até que todos os locais incluídos, estejam em um ou outro grupo, formando assim, o primeiro cluster. 
A metodologia de K.D. Tocher adota o critério de que a média dos valores de $a_{k k}^{2}$, "intra cluster" deve ser menor que os valores de $d_{k k}^{2}$, "inter cluster". Isso é devido à inclusão de grupos adicionais durante a formação de novos "cluster", que altera o valor na média de $\mathrm{d}_{\mathrm{kk}}^{2}$.

o valor máximo permissivel para a inclusão de um novo grupo dentro de um "cluster" pode ser estabelecido arbitrariamente, ou considerar, como foi feito neste trabaIho, o valor máximo de $d_{\mathrm{kk}}^{2}$, encontrado no conjunto das meno res distâncias envolvendo cada local. 


\section{RESULTADOS E DISCUSSÃO}

\subsection{CONDI\&ÕES GERAIS DOS EXPERIMENTOS}

Os experimentos foram instalados nas principais regiões algodoeiras do Paraguai, de modo que, praticamen te todos os tipos de solos e condições climāticas sobre os quais se desenvolve esta cultura estivessem representados no conjunto dos experimentos.

Realizaram-se duas contagens do número de plan tas por parcela, para determinar o nivel ótimo do estande nos experimentos. Os dados da primeira contagem 23 dias após a semeadura, e da segunda, no inicio da colheita, mostraram que a porcentagem de germinação das sementes de todos os genótipos ensaiados foi de 90-95\%, obtendo-se uma população de 80.000 plantas/ha, a qual è recomendada pela pesquisa para a cultura do algodão.

A abertura gradual dos capulhos permitiu realizar, em média, três colheitas manuais, iniciando-se no mês de fevereiro e finalizando no mês de março.

Os dados de distribuição de chuvas, apresentą 
dos nos Apêndices 1 e 2 evidenciam a ocorrência de variações acentuadas na intensidade de precipitação nas principais fases do desenvolvimento da cultura, alterando o compor tamento dos genōtipos, principalmente em relação à produtividade. Entretanto, tais variações não prejudicaram o desen volvimento e a avaliação final dos experimentos.

A utilização de sementes tratadas com inseticidas sistêmicos e fungicidas, assim como o acompanhamento do calendário de controle de pragas garantiu a pequena in cidência das mesmas, durante o desenvolvimento da cultura.

\subsection{ANÁLISE DE VARIÂNCIA}

\subsubsection{Anālise individual}

Os dados considerados neste estudo envolveram seis locais (Pirareta, Ybycui, Caaguazú, Caazapa, Coro nel Bogado e Concepción), dois anos agrícolas (1985/86 e $1986 / 87)$ e 3 e 6 genōtipos, avaliados nestes anos agrícolas, respectivamente.

Convēm ressaltar que o carāter produtividade foi considerado como base para o estudo do presente traba1ho.

Os resultados da análise de variância individual dos dados de produtividade de algodão em caroço, para 
cada ano agrícola são encontrados nos Apêndices 3 a 14. Atrą vés delas, pode ser verificado que os efeitos de tratamentos para o ano 1985/86 foram significativos ao nivel de 5\% de probabilidades pelo teste $F$ para os locais Ybicui, Caaguazú, e Caazapa, sendo que para Pirareta, Coronel Bogado e Concepción os efeitos de tratamentos não apresentaram diferenças significativas.

Da mesma forma para $\circ$ ano de $1986 / 87$ com refé rência a tratamentos, foram encontrados niveis de significân cia pelo teste $F$ ao nível de $5 \%$ de probabilidade para os locais Ybicui, Caaguazú e 1\% de probabilidade paia Concepción, sendo que para Pirareta, Caazapa e Coronel Bogado, não foram detectadas diferenças significativas. Estes efeitos signifi cativos dos tratamentos em diferentes locais, indicam que pe lo menos um deles apresenta comportamento diferencial em relação aos outros.

As anâlises individuais possibilitaram calcular o coeficiente de variação (C.V.) de cada experimento, es timando-se assim a homogeneidade do erro experimental, tendo-se observado amplitude de 6,$61 ; 10,25 \%$ e 7,35; 13,05\% como os menores e maiores C.V., respectivamente, nos experimen tos para cada ano. Essas magnitudes dos coeficientes de variação indicaram uma boa precisão na condução dos experimentos para os diferentes locais em relação ao caráter em es tudo. 


\subsubsection{Anālise conjunta}

Os resultados da anālise conjunta dos experimentos para o ano 1985/86 são apresentados na Tabela $6 . \quad \mathrm{Na}$ apreciação desses resultados verificou-se que os efeitos dos tratamentos apresentaram significância pelo teste $F$ ao nivel de 5\% de probabilidade.

Tabela 6. Anālise conjunta da variância dos dados de produti vidade média de algodão em caroço, em $\mathrm{kg} / 20 \mathrm{~m}^{2}$ de três genōtipos de algodão (Gossypium sp) em seis localidades da região oriental do Paraguai. Ano agrícola $1985 / 86$.

\begin{tabular}{lcccc}
\hline F.V. & G.L. & S.Q. & Q.M. & F \\
\hline Blocos/Locais & 42 & 13,8913 & 0,3307 & $22,04 * *$ \\
Genótipos (T) & 2 & 0,226 & 0,113 & $7,53 *$ \\
Locais (L) & 5 & 38,602 & 7,720 & $23,34 * *$ \\
Genōtipos x Locais & $10(6)$ & 0,393 & 0,039 & $2,62 *(*)$ \\
Erro mēdio ponderado & $84(14)$ & 1,260 & 0,015 & \\
\end{tabular}

Média: 3,68

$C \cdot V \cdot(\%): 8,06$

* Significativo ao nível de 5\% de probabilidade

* Sigilificativo ao nivel de $1 \%$ de probabilidade.

(*) Significância de $F$ com 6 e 14 GL, sendo $\eta_{r}=6$ e $\eta_{r}^{\prime}=14$ conforme PIMENTEL GOMES (1985).

Por outro lado, houve divergência significati va para os efeitos de locais e para a interação genótipo $x$ 
locais. A significância da interação, detectada pela anālise conjunta, revelou uma ação diferencial dos genótipos em diferentes locais. Isto jā era de se esperar, uma vez que, uma simples observação no comportamento individual dos locais fornece uma idéia do comportamento diferencial dos mesmos.

No estudo da interação genōtipos $\mathrm{x}$ ambientes, FALCONER (1983). salienta que pode-se admitir que uma diferença específica de ambientes possua o mesmo efeito sobre genótipos ou, em outras palavras, que pode-se associar certos desvios ao ambiente, com uma diferença de ambiente independente do genótipo, sobre o qual ela age. Tal não foi observado para significância da interação.

Na Tabela 7 são encontrados os valores relati vos às médias de produtividade dos genótipos em cada local, assim como as suas médias marginais. Analisando-se o compor tamento dos genōtipos atravēs de suas produtividades médias, pode-se observar que a variedade Reba $\mathrm{P}-279$ e a linhagem SP-510 x P-279-100 mostraram rendimentos superiores à média geral, sendo que SP-510 x P-279-22 mostrou rendimento inferior a média geral e tambēm inferior à Reba p-279 e SP-510 x P-279-100. No entanto, entre a Reba P-279 e SP-510 x P-279100 não houve diferenças significativas ao nivel de $5 \%$ de probabilidades pelo teste Tukey.

A Iinhagem $\mathrm{SP}-510 \times \mathrm{P}-279-22$, apesar do seu comportamento diferencial em relação aos outros, deve ser 
50.

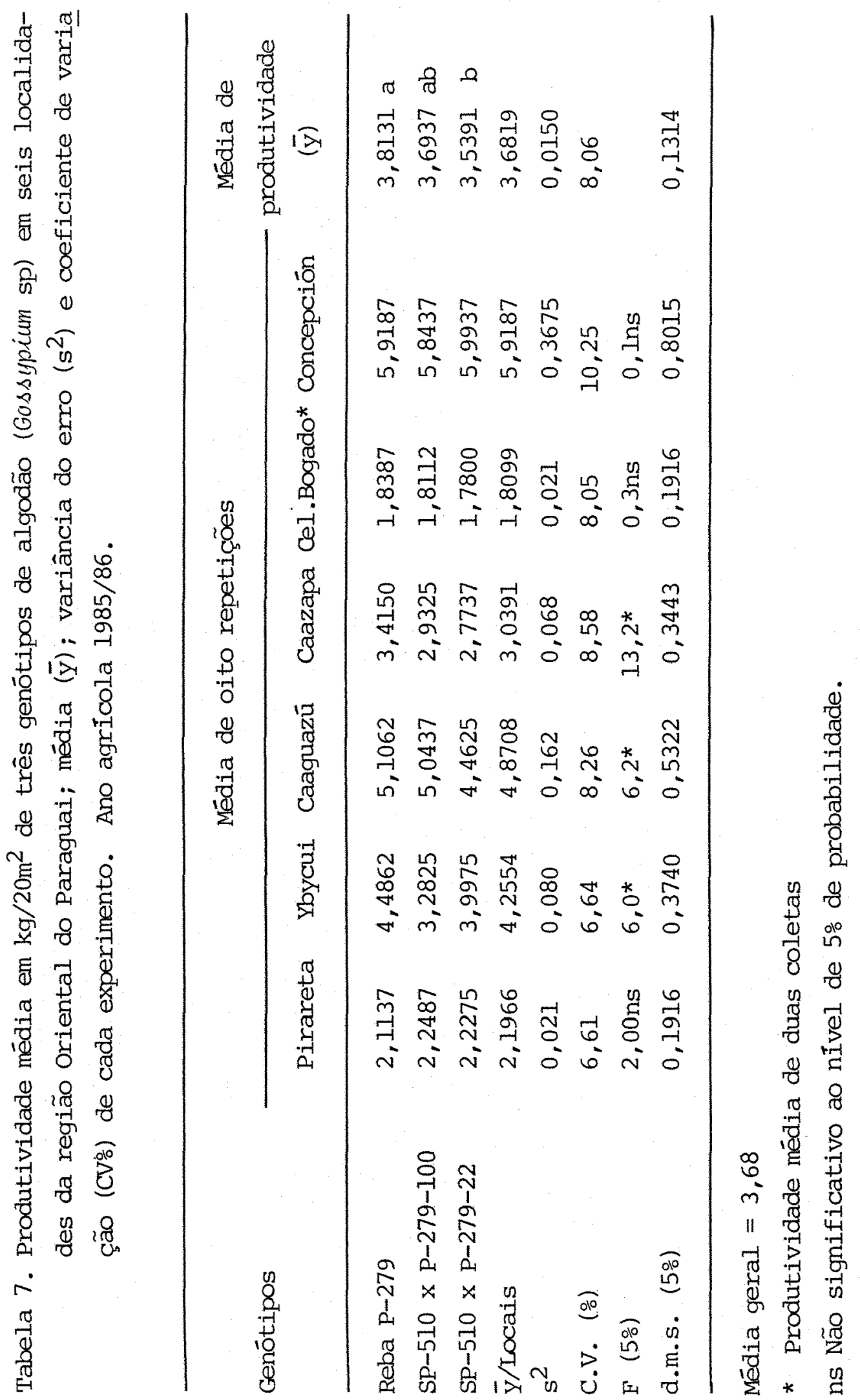


considerado pela sua precocidade, carāter muito importante na seleção de genótipos com esta característica. Uma análí se do comportamento dos genótipos nos diferentes locais mos tra que eles são relativamente homogêneos dentro de cada local, mas diferiram muito de um local para outro. Pode-se perceber que em Ybycui, Caaguazú e Concepción as produtividades médias foram superiores à média geral, no entanto, nos outros locais não atingiram valores próximos em relação à média.

Deve-se considerar que as alterações ambientais tiveram acentuada influência sobre o comportamento dos diferentes genótipos. O fator chuva, medido como precipitação pluviométrica em mm (Apêndice 1) constituiu o componente ambiental mais variāvel durante o ciclo, afetando principalmente a etapa inicial de desenvolvimento da cultura.

Da mesma forma, as análises conjuntas da va riância para o ano $1986 / 87$ são encontrados na Tabela 8 . Co mo pode ser observado, foram detectados efeitos significati vos para os genótipos e locais, assim como para as interações entre ambos. As interações significativas monstraram a influência das variações ambientais previsiveis e/ ou imprevisiveis (ALLARD \& BRADSHAW, 1964) no desempenho diferencial dos genótipos.

Os valores médios de proulutividade de algodão em caroço para cada ambiente estão apresentados na Tabela 9. Apesar dos genótipos terem mostrado comportamento médio dife rentes, apenas a linhagem SP-510 x P-279-38/41 e SP-510 x 
P-279 28/39 foram estatisticamente inferiores a todos os outros genótipos. A linhagem SP 510 x P-279-32 destacou-se das demais, por ter apresentado produtividade média relativamente superior $\left(5,7312 \mathrm{~kg} / 20 \mathrm{~m}^{2}\right)$.

Tabela 8. Análise conjunta da variância dos dados de produti vidade média de algodão em caroço em $\mathrm{kg} / 20 \mathrm{~m}^{2}$ de no ve genótipos de algodão (Gossypium sp) em seis localidades da região Oriental do Paraguai. Ano agrí cola $1986 / 87$.

\begin{tabular}{lrrrc}
\hline F.V. & G.I. & S.Q. & Q.M. & F \\
\hline Blocos/locais & 18 & 39,6797 & 2,2044 & $35,15 * *$ \\
Genótipos (T) & 8 & 2,9405 & 0,3675 & $5,86 *$ \\
Locais (L) & 5 & 86,8942 & 17,3788 & $7,88 * *$ \\
Genótipos x Locais & 40 & 6,2768 & 0,1569 & $2,50 * *$ \\
Erro médio ponderado & 144 & 8,9635 & 0,0627 & \\
& & & & \\
Média: 5,48 & & C.V. (.) : 9,21 & \\
\hline
\end{tabular}

* Significativo ao nível de 5\% de probabilidade

** Significativo ao nível de $1 \%$ de probabilidade. 
53.

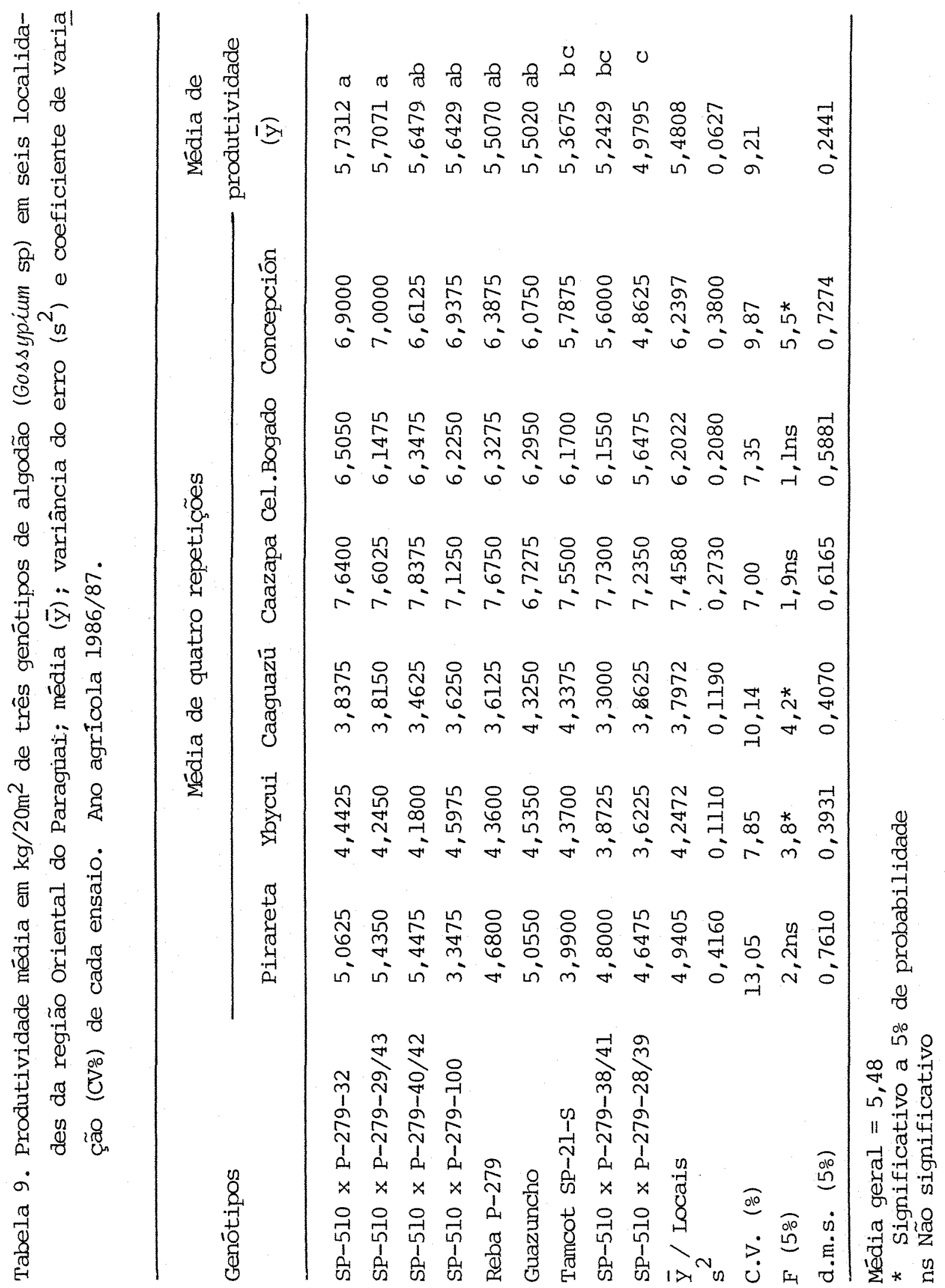


o comportamento de diferentes genótipos em am bientes diversificados é importante para o melhorista não so mente do ponto de vista da magnitude da interação, mas tambēm adquire um sentido essencialmente prático, com respeito às múltiplas possibilidades para o aproveitamento adequado do potencial genético existente no material.

Comparando-se as produtividades médias dos ge nótipos, tomando-se a Reba P-279 como 100, foram observados comportamentos superiores em $3,82 \%, 2,38 \%, 2,55 \%$ e 2,46\% das linhagens SP-510 x P-279-32, SP-510 x P-279-29/43, SP$510 \times \mathrm{P}-279-40 / 42$ e SP $510 \times \mathrm{P}-279-100$, respectivamente. No entanto, Guazuncho e Tamcot SP-2I-S tiveram um comportamento pro dutivo relativamente inferior a Reba $\mathrm{P}-279 \mathrm{em} 0,1 \%$ e 2,5\%, respectivamente, mas foram superiores aos genótipos SP-510x $\mathrm{P}-279-38 / 41$ e SP-510 x P-279-28/39.

Apesar de não terem sido consideradas nas anālises para o caráter precocidade, a variedade Guazuncho e a linhagem Tamcot SP-2l-S foram consideradas as mais precoces, seguidas pelas linhagens SP-510 x Reba P-279-38/41 e SP-510x Reba P-279-28/39, respectivamente.

o coeficiente de variação foi de 9,21\%, indicando um nivel aceitável de confiabilidade nos resultados obtidos nos seis locais. 


\subsection{AnAlise de estabiliddade}

E uma prática comum em estudos genéticos e en saios de variedades, testar uma série de genōtipos numa ampla faixa de ambientes. Se todos os genótipos respondem de maneira similar a todos os ambientes testados, seu comportamento relativo em outros ambientes pode ser previsto com certa segurança. Contudo, existem diferenças no comportamen to relativo, tornando-se necessário uma anālise do padrão de variação tanto dentro, como entre locais dentro dos genötipos, para determinar quais respundem diferencialmente uns dos outros.

Na Tabela 7 estão apresentadas as médias de produtividade de algodão em caroço para os seis locais da re gião Oriental do Paraguai, para o ano 1985/86. Também são apresentadas as médias por locais e os coeficientes de varia ção (CV응.

Os dados mostram que houve uma grande flutuação na produtividade de algodão em caroço de local para local, desde $1,8099 \mathrm{~kg} / 20 \mathrm{~m}^{2}$ em Coronel Bogado, atē $5,9187 \mathrm{~kg} /$ $20 \mathrm{~m}^{2}$ em Concepción.

A anālise da variāncia conjunta segundo a metodologia de EBERHART \& RUSSELT (1966) está apresentada na Tabela 10. Observa-se que houve diferenças significativas entre os genōtipos, e estas mostraram interação significativa com os locais. Tambēm foram significativos os componentes: ambien- 
56.

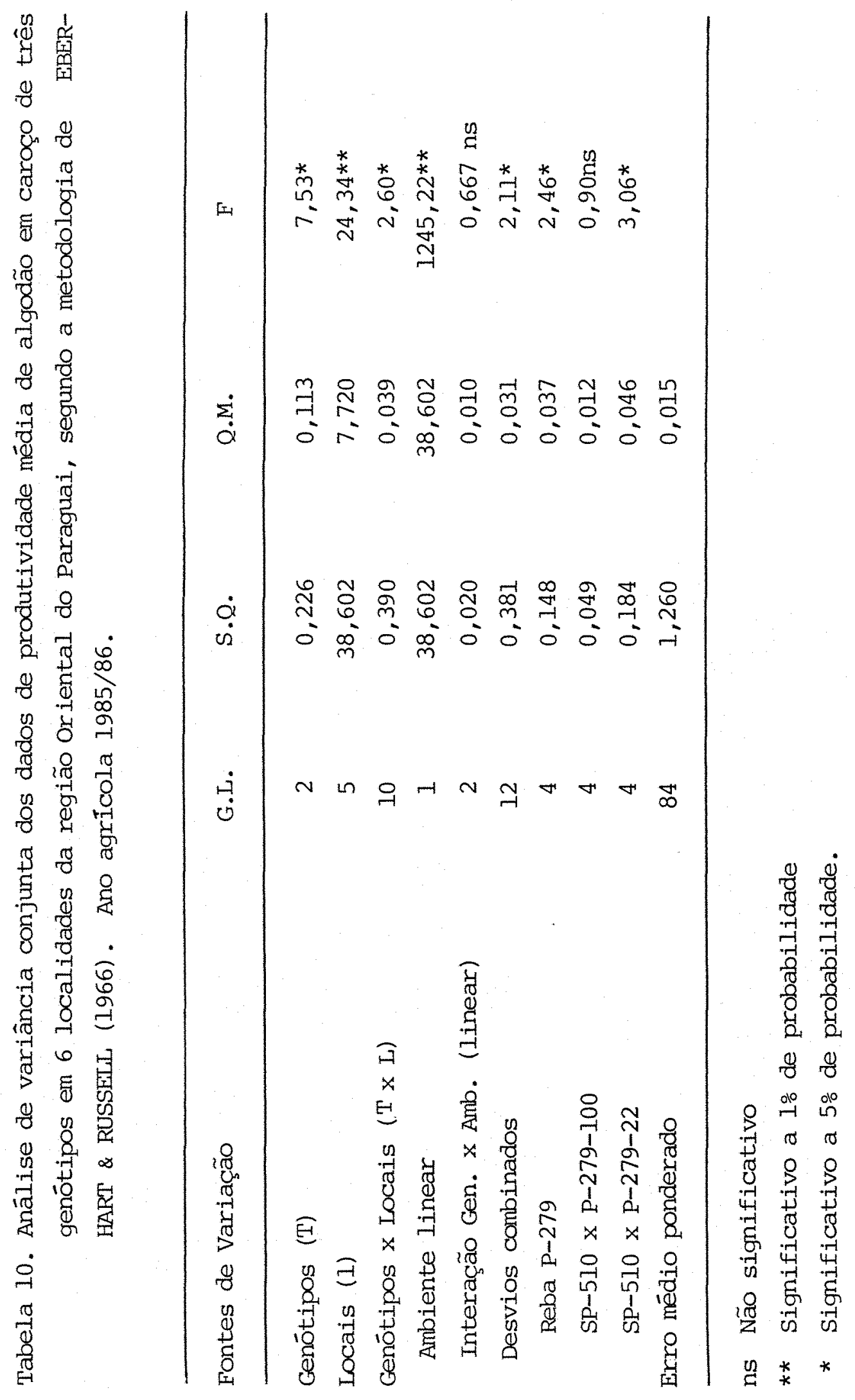


te (linear), e os desvios de regressão combinados, resultados da decomposição da soma de quadrados de genótipos $\mathrm{x}$ ambientes. A não significância da interação genótipos x local (linear) indica que não houve diferenças significativas entre os coeficientes de regressão para cada genótipo.

$\mathrm{Na}$ Tabela 11 encontram-se as estimativas das produtividades médias, coeficiente de regressão e desvios de regressão, este último obtido pela diferença entre o quadrado médio dos desvios das regressões e o quadrado médio do erro médio ponderado, assim como os coeficientes de determinação para cada cultivar.

Tabela 11. Estimativas dos parâmetros de estabilidade de pro dutividade de algodão em caroço de três genótipos segundo a metodologia de EBERHART \& RUSSELL (1966). Ano agrícola 1985/86.

\begin{tabular}{lcccc}
\hline Genótipos & $\begin{array}{l}\text { Produti } \\
\text { vidade } \\
\text { média } \\
\left(\mathrm{kg} / 20 \mathrm{~m}^{2}\right)\end{array}$ & $\begin{array}{c}\text { Coeficien } \\
\text { te de re- } \\
\text { gressão } \\
\left(\mathrm{b}_{\mathrm{i}}\right)\end{array}$ & $\begin{array}{c}\text { Desvios } \\
\text { da re } \\
\text { gressão } \\
\mathrm{S}^{2} \mathrm{~d}(\mathrm{~b})\end{array}$ & $\begin{array}{c}\text { Coeficien- } \\
\text { te de de- } \\
\text { terminação } \\
\mathrm{R}^{2}(\mathrm{~b})\end{array}$ \\
\hline Reba P-279 & 3,81 a & 1,02 & $0,021986 *$ & 0,99 \\
SP-510 x P-279-100 & 3,69 ab & 1,00 & $0,002835 \mathrm{~ns}$ & 1,00 \\
SF-510 x P-279-22 & 3,54 b & 0,98 & $0,030169 *$ & 0,99 \\
-
\end{tabular}

Média geral: $\quad 3,69 \mathrm{~kg} / 20 \mathrm{~m}^{2}$

Médias seguidas pelas mesmas letras não diferem significativamente pelo teste Tukey ao nivel de 5\% de probabilidade.

* Significativo ao nível de $5 \%$ pelo teste $\mathrm{F}$. 
Adotando-se o critērio descrito no item 3.2.2, e considerando que os valores do coeficiente de regressão ( $b_{i}$ ) e das variâncias dos desvios $\left(S^{2} d\right)$ para cada genótipo são vạ lores relativos à avaliação da estabilidade, estes devem ser discutidos em termos comparativos.

A cultivar Reba P-279 possui uma boa produtividade, com um coeficiente de regressão indicando adaptação geral, porēm os desvios significativos compromete sua produtividade em ambientes específicos. No entanto, a cultivar SP-510 × P-279-100 apresenta uma produtividade superior a média, um coeficiente de regressão não significativamente di ferente de 1 , indicando uma ampla adaptação. Os desvios da regressão não significativos, por sua vez, indicaram alta es tabilidade de resposta ou boa previsibilidade.

o único genótipo que possui o desvio da regressão não significativo é SP-510 x P-279-100. Observa-se tambēm, pelo seu coeficiente de determinação $\left(R^{2}\right)=1,00$, que demonstra uma alta adequação do modelo para explicar a flutuação de produtividade em função das flutuações ambientais, dando validade às afirmações anteriores.

Os outros genótipos são menos estāveis ou prẹ visiveis segundo este critério de avaliação, porque possuem os desvios da regressão significativos, ou seja, um menor grau de adequação ao modelo.

A Figura 2 apresenta o gráfico sobre $\circ$ comportamento dos genótipos Reba P-279, SP-510 x P-279-100 e SP-510. $\times \mathrm{P}-279-22$. 
59.

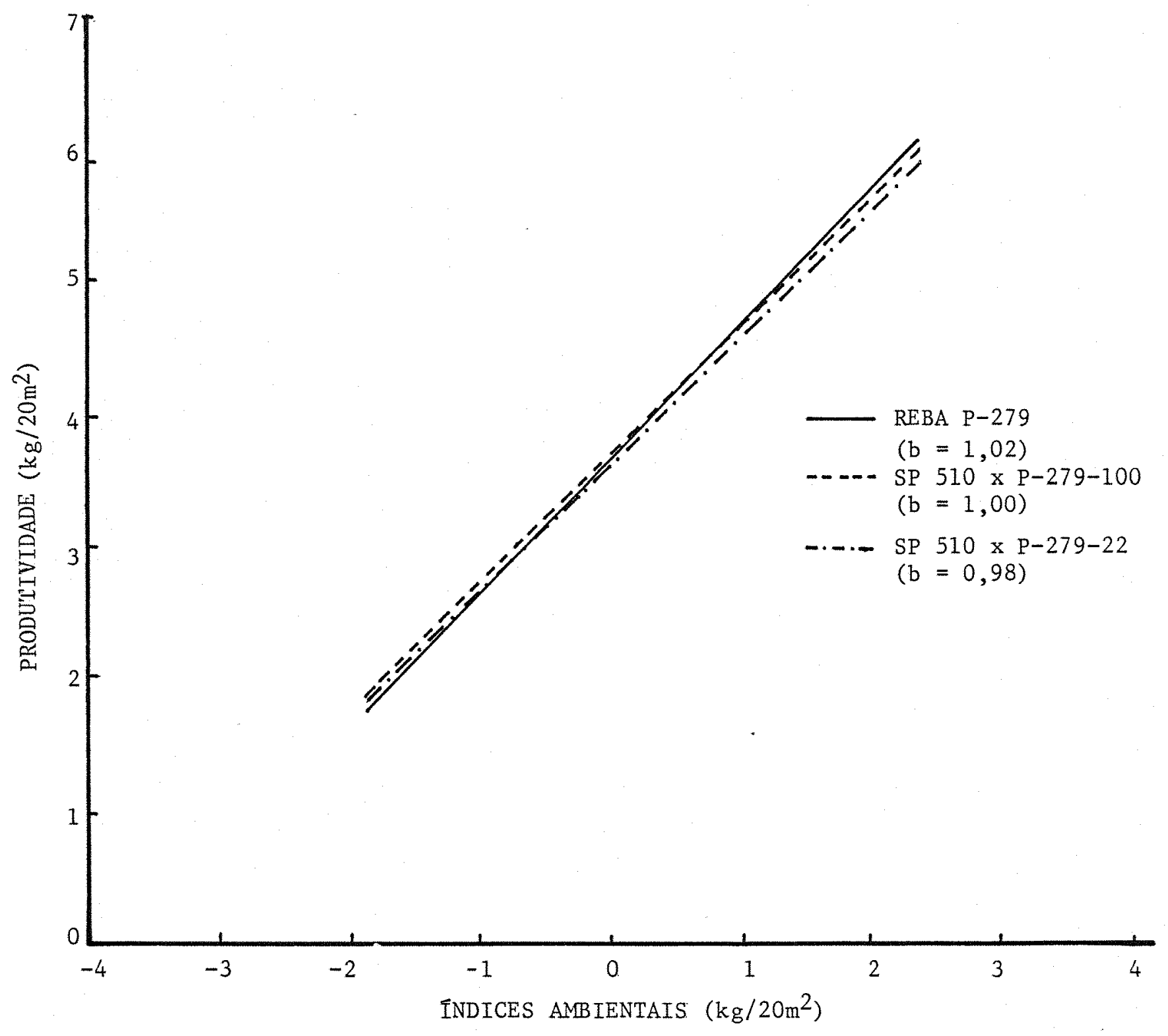

Figura 2. Representação gräfica da produtividade de algodão en caroço dos genótipos de algodão (Gossypium sṕ) en função dos Indices ambien tais. Ano agrícola $1985 / 86$. 
60.

Para o ano $1986 / 87$, as médias de produtividade de algodão em caroço nos seis locais estão apresentadas na Tabela 9. Da mesma forma que no ano anterior, observou-se diferenças nas médias de produtividades de um local para outro. Os dados da Tabela 9 mostram que houve flutuações de $3,7972 \mathrm{~kg} / 20 \mathrm{~m}^{2}$ em Caaguazū atē $7,4580 \mathrm{~kg} / 20 \mathrm{~m}^{2}$ em Caazapa.

Na Tabela 12 são encontradas as análises de variância conjunta segundo a metodologia de EBERHART \& RUSSELL (1966). Percebe-se que foram detectadas diferenças sig nificativas para genótipos, locais e para as interações. Tam bēm foram observadas significâncias para os componentes: ambiente linear, genótipos x local (linear) e os desvios combinados. A decomposição dos efeitos lineares para cada genótipo mostrou significância para alguns deles.

A significância estatística da interação de genótipos $x$ ambientes linear mostra que houve diferença entre os coeficientes de regressão linear para cada genótipo.

A Tabela 13 mostra as estimativas dos parâmetros de estabilidade, produtividade média $(\bar{y})$, coeficiente de regressão linear $\left(b_{i}\right)$, variância dos desvios $\left(s^{2} d\right)$ e coeficientes de determinação dos nove genōtipos nos seis 10cais. A comparação das produtividades médias mostram diferenças nas suas magnitudes segundo teste de Tukey a 5\% de pro babilidade. Os coeficientes de regressão linear e os desvios da regressão para alguns genótipos testados neste ano foram significativos através do teste de F. 
61.

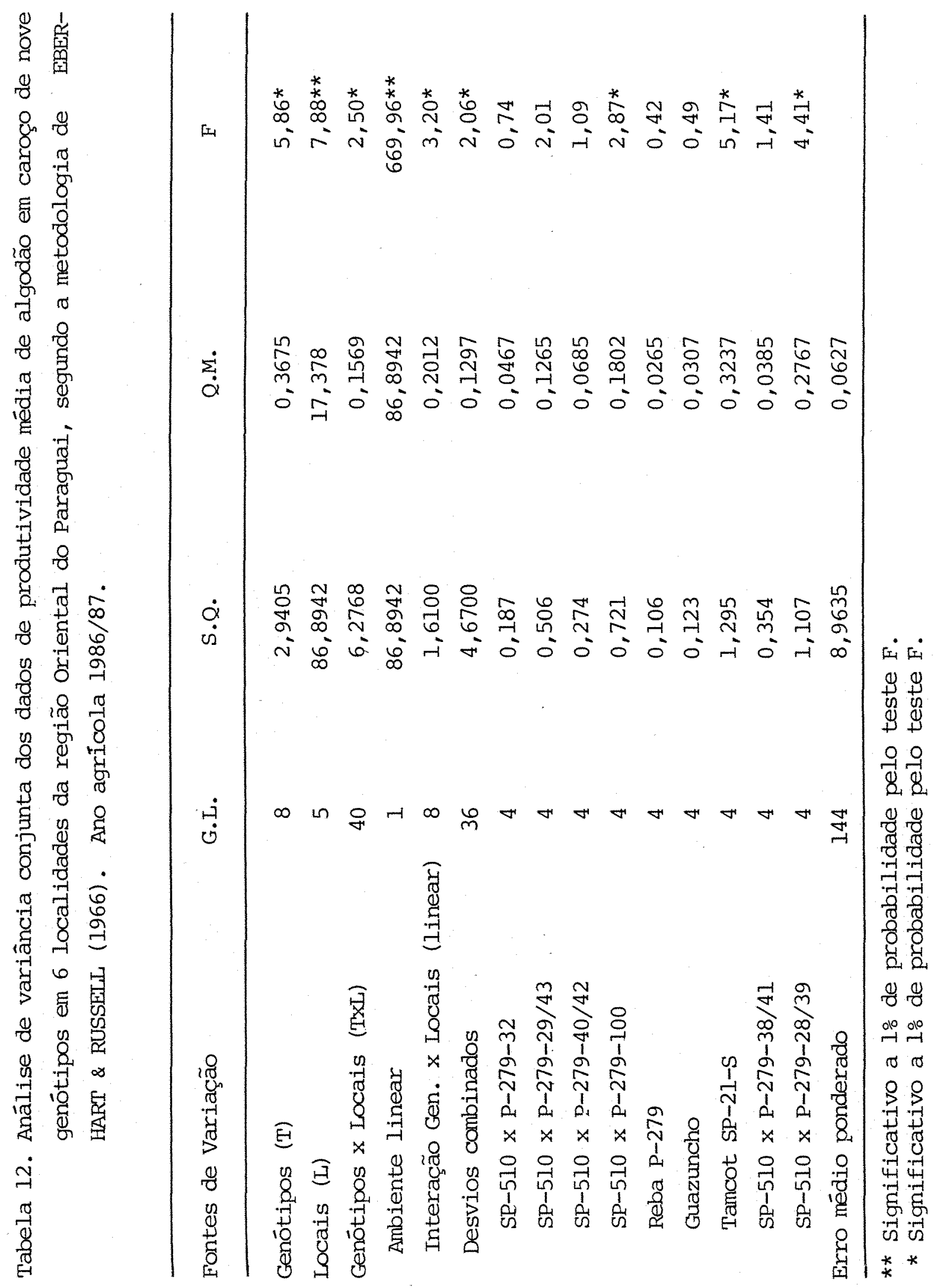


Tabela 13. Estimativas dos parāmetros de estabilidade de pro dutividade de algodão em caroço de nove genótipos lGos sypium $\mathrm{sp})$, segundo a metodologia de EBERHART \& RUSSELL (1966). Ano agrícola 1986/87.

\begin{tabular}{|c|c|c|c|c|}
\hline Genōtipos & $\begin{array}{c}\text { Produtividads } \\
\text { média } \\
\left(\mathrm{kg} / \frac{20}{\mathrm{y}} \mathrm{m}^{2}\right) \\
\end{array}$ & $\begin{array}{l}\text { le coef. } \\
\text { regressão } \\
\left(b_{i}\right)\end{array}$ & $\begin{array}{c}\text { Desvios da } \\
\text { regressão } \\
s^{2} a(b)\end{array}$ & $\begin{array}{l}\text { Coef. de } \\
\text { determinação } \\
\mathrm{R}^{2}(\mathrm{~b})\end{array}$ \\
\hline SP510 $\times$ P $-279-32$ & $5,7312 a$ & 1,07 & $0,0194 \mathrm{ins}$ & 0,98 \\
\hline SP510 $\times \mathrm{P}-279-29 / 43$ & $5,7071 a$ & 1,05 & $0,060 \mathrm{~ns}$ & 0,96 \\
\hline SP510 × P.279-40/42 & $5,6467 a b$ & $1,15^{*}$ & $0,0022 \mathrm{~ns}$ & 0,98 \\
\hline SP510 x P.279-100 & $5,6429 a b$ & 0,96 & $0,1138 \mathrm{~ns}$ & 0,93 \\
\hline Reba $\mathrm{P}-279$ & $5,507 \mathrm{Cab}$ & $1,10^{*}$ & $0,03972 n s$ & 0,99 \\
\hline Guazuncho & $5,5020 \mathrm{adb}$ & 0,71 & $0,0353 \mathrm{~ns}$ & 0,98 \\
\hline Tamcot SP-21-S & $5,3675 \mathrm{bc}$ & 0,92 & $0,2573 * *$ & 0,86 \\
\hline SP510 x P.279-38/41 & $5,2429 \mathrm{bc}$ & $1,14^{*}$ & $0,0221 \mathrm{~ns}$ & 0,97 \\
\hline SP510 × P.279-28/39 & $4,9795 \mathrm{C}$ & 0,89 & $0,2104 * *$ & 0,87 \\
\hline
\end{tabular}

Média geral: $5,48 \mathrm{~kg} / 20 \mathrm{~m}^{2}$

Médias seguidas pelas mesmas letras não diferem significativamente pelo teste de Tukey ao nível de 5\% de probabilidade.

** Significativo ao nível de 5\% de probabilidade pelo teste F'. ns Não significativo. 
O coeficiente de regressão apresentado na Tabela 13 mostra o maior valor $(b=1,15)$ para a linhagem SP$510 \times$ P-279-40/42, indicando maior capacidade deste genótipo em responder aos estimulos ambientais favoráveis. O menor valor do coeficiente de regressão linear $(b=0,71)$ obtido para a variedade Guazuncho, indica uma adaptação maior aos ambientes de baixa produtividade.

Os genótipos SP-510 x P-279-32, SP-510 x P279-29/43, SP-510 x P-279-100, Guazuncho, Tamcot SP 21-S e SP-510 x P-279-28/39 tem adaptação geral, já que os coeficí entes de regressão não aiferem significativamente de 1 . No entanto, a SP-510 × P-279-40/42, Reba P-279 e SP-510 x P-279$38 / 41$ possuem adaptação específica a ambientes mais promisso res pelo fato de apresentarem coeficientes de regressão para estabilidade significativamente maiores que 1.

As linhagems que apresentaram valores dos desvios da regressão significativos foram a Tamcot SP-21-S e a SP-510 × P-279-28/39, monstrando que são materiais menos estāveis ou previsíveis, ou seja, com menor grau de adequação ao modelo. Os outros materiais possuem va lores dos desvios da regressão não significativos, monstran do pelos seus coeficientes de determinação que possuem uma alta adequação do modelo para explicar a flutuação na produtividade em função das flutuações ambientais.

Na Figura 3, está apresentado um gráfico demonstrando o comportamento da produtividade de algodão em cá 
64.

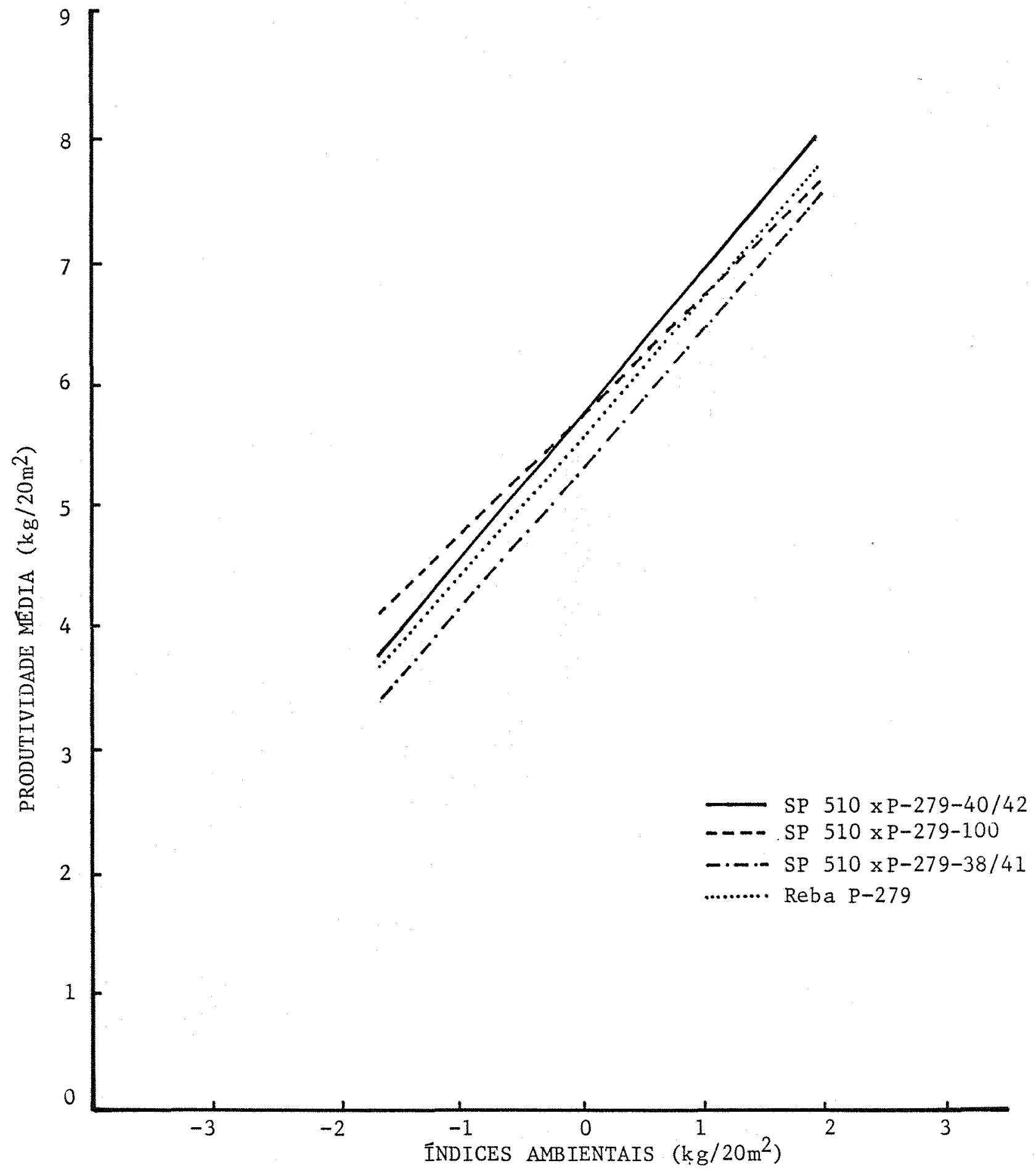

Figura 3. Representação gräfica da produtividade de nove genōtipos de algodão (Gossypium sp.) em função dos indices ambientais. Ano agricola $1986 / 87$. 
roço dos genótipos SP-510 x P-279-100, SP-510 x P-279-40/42, SP-510 x P-279-38/41 e a Reba P-279.

A linhagem SP-510 x P-279-100 possui uma boa produtividade, com um coeficiente de regressão indicando adap tação geral, e com desvio da regressão não significativo, con firmando sua estabilidade numa ampla faixa de ambientes.

\subsection{Classificacão de ambientes}

Neste estudo foram utilizados mātodos de clas sificação numérica para verificar se os locais onde foram con duzidos os experimentos podem ser considerados como membros do grupo (regiões) parcialmente dissociados, ou melhor, se existe entre os locais estudados, padrões de interação similares em relação aos genótipos utilizados.

A classificação de locais foi efetuada dentro de cada ano, sendo esta uma análise que tem por objetivo dar uma visão conjunta das similaridades entre todos os locais das atuais regiões produtoras de algodão do país.

Na Tabela 7 encontram-se as médias de produti vidade dos três genótipos estudados em cada e em todos os lo cais no agricola 1985/86. A partir destes dados foram obtidas as matrizes dos valores da interação genótipos x locais (Tabela 14).

As distâncias entre todos os possiveis pares de locais para cada uma das matrizes de interação genótipos $x$ locais estão apresentados na Tabela 15. 
66.

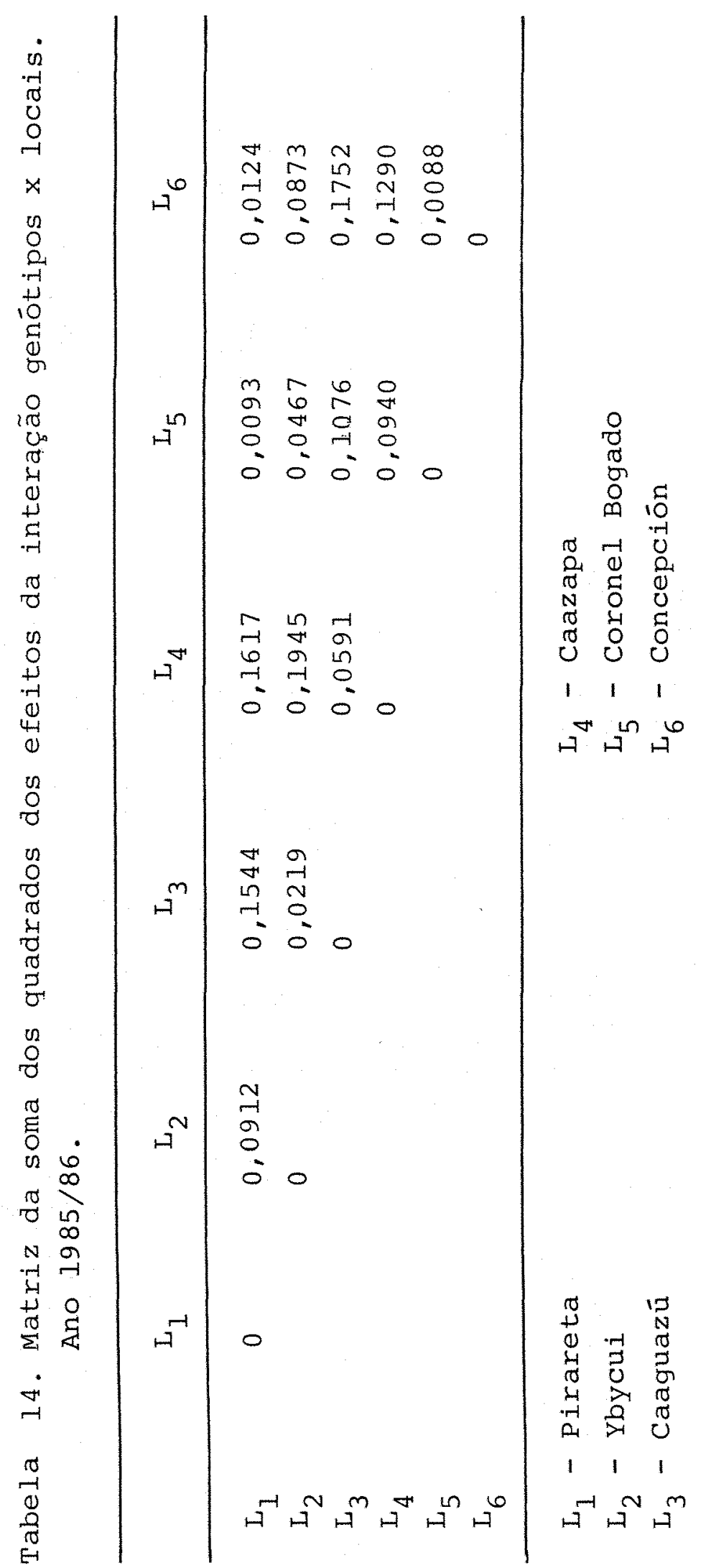


67.

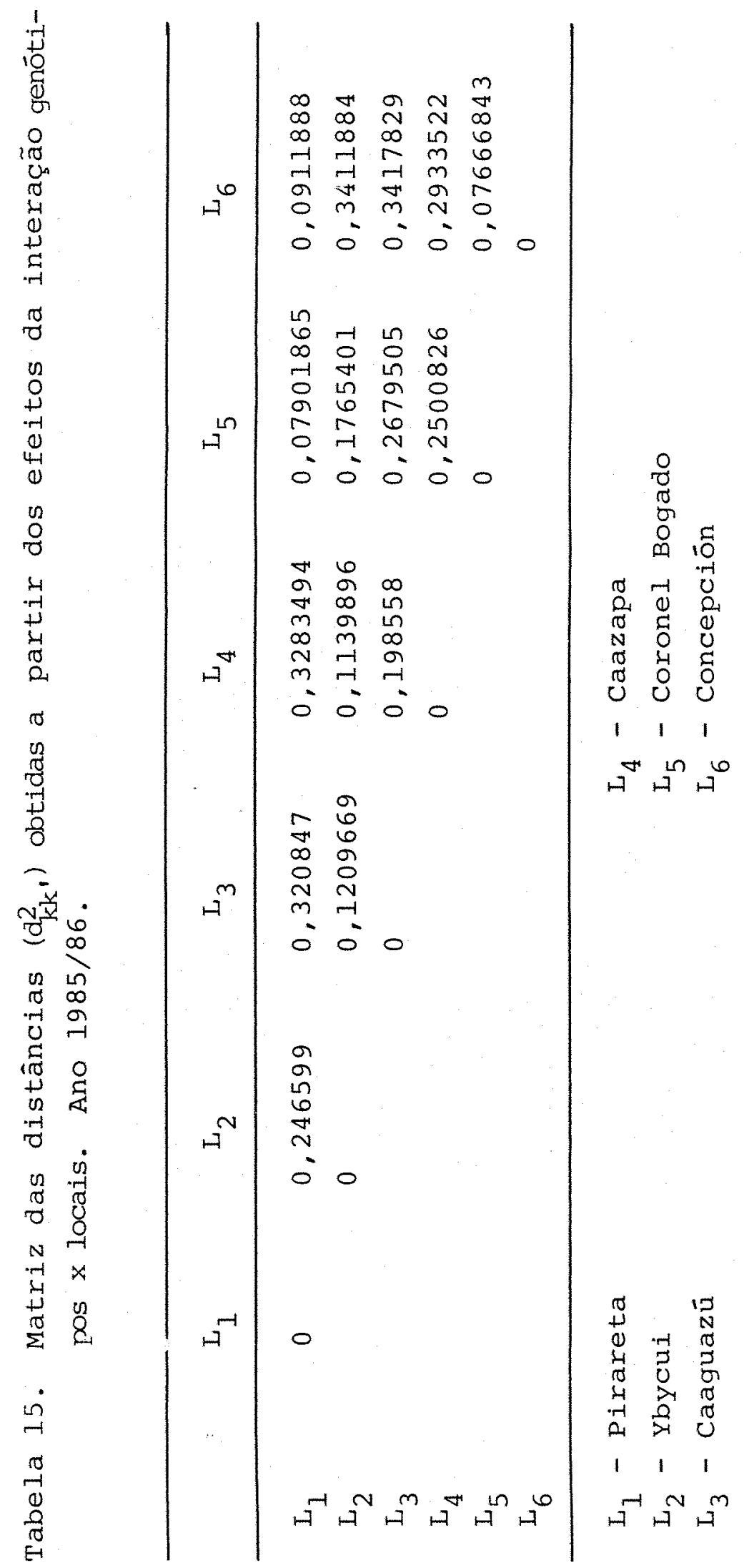


o agrupamento de locais resultante da aplicação do método de Tocher (RAO, 1952), descrito no item 3.2.3.2 é apresentado na Tabela 16 .

Tabela 16. Agrupamento dos locais segundo a metodologia de K.D. Tocher (RAO, 1952) para o ano 1985/86.

\begin{tabular}{ll} 
Grupos & Ambientes \\
\hline$I$ & $I_{1}, I_{5}, I_{6}$ \\
$I I$ & $I_{2}, I_{4}$ \\
$I I I$ & $I_{3}$ \\
\hline$L_{1}-$ Pirareta & $I_{4}-$ Caazapa \\
$L_{2}-$ Ybycui & $I_{5}-$ CoroneI Bogado \\
$I_{3}-$ Caaguazú & $I_{6}-$ Concepción
\end{tabular}

As relações neste agrupamento foram baseadas na performance diferencial de produtividade de três genōtipos testados em seis locais durante o ano 1985/86. Essas re lações entre os locais indicaram que o local L 1 (Pirareta) teve um padrão de interação similar àquele do local $\mathrm{L}_{5}$ (Coro nel Bogado) e do local $L_{6}$ (Concepciōn), formando assim o gru po I. Da mesma forma, os locais $\mathrm{L}_{2}$ (Ybycui) e $\mathrm{L}_{4}$ (Caazapa) apresentaram considerável grau de semelhança possibilitando a formação do grupo II. O local $I_{3}$ (Caazapa) não mostrou ' qualquer grau de similaridade com as localidades remanescentes, fican do isolada no grupo III. 
A seguir, serão discutidos os resultados do ano agrícola 1986/87. As médias de produtividade, interações e coeficientes das distâncias estão apresentados nas Tabelas 17 e 18, respectivamente.

As relações de grupos estabelecidos entre as localidades foram baseadas no padrão da interação de nove ge nótipos. O agrupamento dos ambientes atravēs da metodologia de K.D. Tocher (RAO, 1952) è apresentado na Tabela 19. observa-se que o primeiro grupo foi formado pelos locais $I_{5}$ (Coronel Bogado), $I_{2}$ (Ybycui), $I_{3}$ (Caaguazū) e $\mathrm{L}_{4}$ (Caazapa), os quais apresentaram padrões de similaridades, embora estejam geograficamente distantes.

$$
\text { Os locais } L_{6} \text { (Concepciōn) e } L_{1} \text { (Pirareta) não }
$$

mostraram similaridades com nenhum outro local, tanto que ficaram isolados, formando o segundo e terceiro grupo respecti vamente.

Os resultados das anālises de classificação permitem algumas indicações sobre aspectos que devem ser con siderados na proposição de um zoneamento. Essas observações estão obviamente condicionadas às caracteristicas especificas dos genótipos e locais utilizados nos experimentos, à sua variabilidade de ano para ano e à Aistribuição dos locais na ārea geográfica em estudo.

$$
\text { Pode-se perceber a inconsistência no agrupa- }
$$
mento de um ano para outro. A proposição de um zoneamento não pode ser formulado a partir dos resultados obtidos neste 
70.

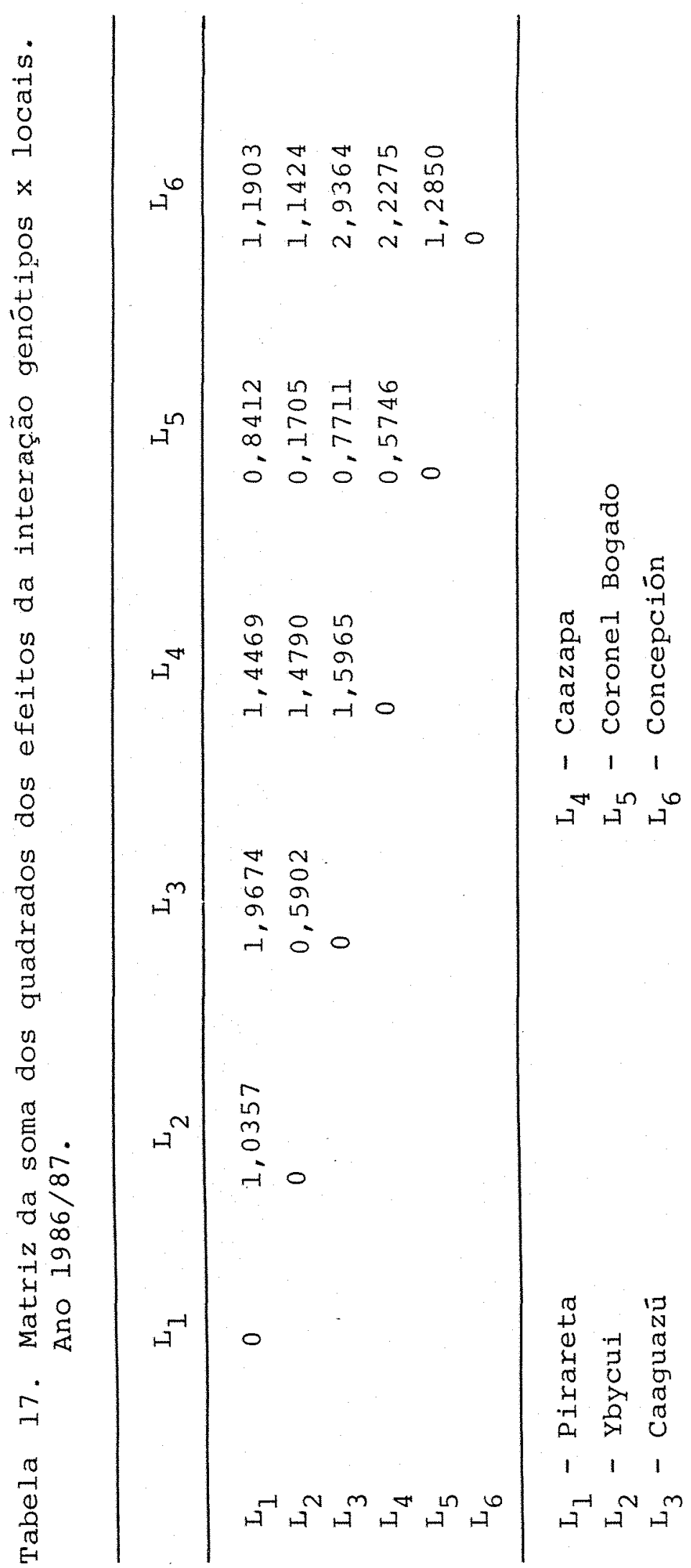


71.

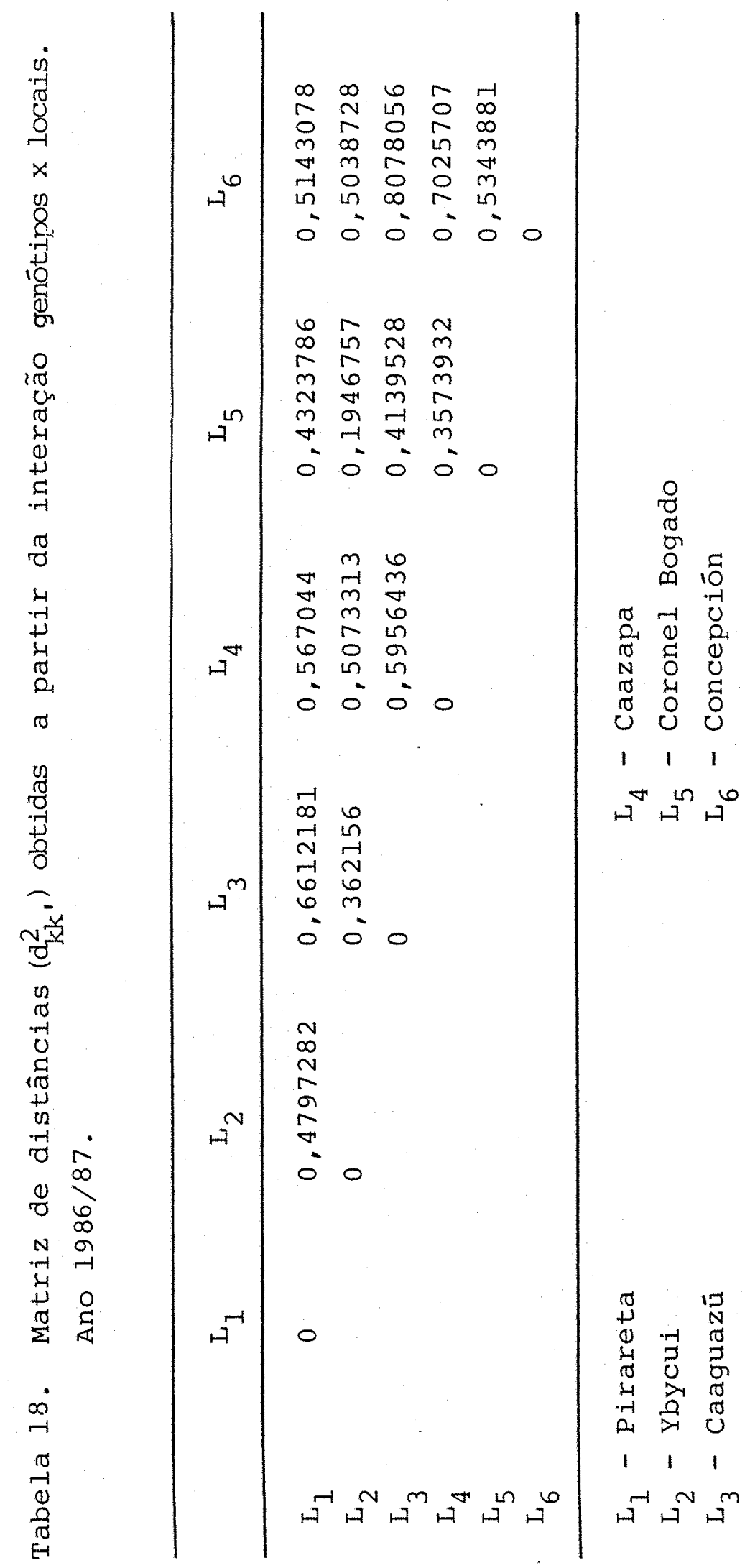


trabalho. Pode-se atribuir a tal fato à insuficiência dos dados utilizados, especificamente ao nümero reduzido de tra tamentos e falta de homogeneidade dos mesmos de um ano para outro, sujeitos à grande complexidade do problema.

Tabela 19. Agrupamento de locais segundo a metodologia de K.D. Tocher (RAO, 1952), para o ano 1986/87.

\begin{tabular}{ll}
\hline Grupos & Locais \\
\hline$I$ & $L_{5}, L_{2}, L_{3}, L_{4}$ \\
$I I$ & $L_{6}$ \\
$I I$ & $L_{1}$ \\
\hline$L_{1}-$ Pirareta & $L_{4}-$ Caazapa \\
$L_{2}-$ Ybicui & $L_{5}-$ Coronel Bogado \\
$L_{3}-$ Caaguazú & $L_{6}-$ Concepción
\end{tabular}




\section{CONCLUSÕES}

Os resultados obtidos no presente trabalho, permitiram as seguintes conclusões:

- Ao nível de análises individuais, foram detectadas variações significativas entre os genótipos testados nos dois anos de estudo, mostrando que houve variabilida de genética entre as mesmas. As variações observadas, quanto à sua magnitude, foram maiores entre os diferentes ambien tes do que entre genótipos dentro de ambientes.

- A interação genótipo $x$ ambientes influiu sig nificativamente na variabilidade intergenotipica do caráter estudado.

- Para a produtividade, as alterações ambien tais tiveram influência prejudicial no comportamento dos genótipos, sendo a variação das precipitações pluviométricas nas etapas de desenvolvimento inicial das plantas, a que exer ceu maiores efeitos no desempenho diferencial dos genótipos. 
- As anālises de variância conjunta envolvendo três genótipos e seis localidades para o ano 1985/86 e nove genótipos com o mesmo número de localidades para $\circ$ ano 1986/87, tambēm relataram variações significativas entre genótipos para o caráter estudado.

- Considerando o método estabelecido por EBERHART \& RUSSELL (1966) para estudos de estabilidade, o coeficiente de regressão linear $\left(b_{i}\right)$ mostrou que o comportamento dos genótipos, tanto para o ano 1985/86 quanto para 1986/87, apresentaram uma adaptação geral, com exceção dos genótipos SP-510 x P-279-40/42, Reba P-279 e SP-510 x P-279-38/ 41 que apresentaram tendências à especificidade de adaptação em ambientes mais promissores. Em função da significância dos desvios da regressão que avaliam a previsibilidade dos genótipos, somente os genötipos TAMCOT SP-21-S e SP-510 x P-27928/39 apresentaram valores significativos, sendo que as demais mostraram adaptação ao modelo estabelecido para o presente trabalho.

- A metodologia de K.D. Tocher (RAO, 1952), utilizada para o agrupamento de locais, mostrou que as infor mações obtidas estão sujeitas às restrições quanto ao número de genótipos e locais utilizados em cada ano, prejudicando assim a validade dos resultados. Por outro lado, o número de repetições dos experimentos ofereceram pouca representatividade das condições climāticas inerentes à ārea geogrā- 
fica em estudo. A proposição de um zoneamento não pôde ser formulada a partir dos resultados obtidos no trabalho, devido à insuficiência dos dados utilizados, particularmente no que se refere ao nümero de genótipos e anos, complementado pe la grande complexidade do problema.

- A realização de estudos de zoneamento ecoló gico implica na utilização de dados experimentais com maior nümero de ambientes uniformemente distribuídos sobre a área de interesse, durante um certo número de anos e com razoável nümero de genótipos comuns. Isto possibilitaria a classificação de ambientes livres da tendenciosidade provocada pela interação genótipos $\mathrm{x}$ anos. 


\section{REFERÊNCIAS BIBLIOGRAFICAS}

ABOU-EL-EITTOUH, H.A.; RAWLINGS, J.O.; MILLER, P.A. Classifi cations of environments to control genotype by environment interaction with aplication to cotton. Crop Science, Madison, $\underline{9}$ : 135-40, 1969a.

ABOU-EL-FITTOUH, H.A.; RAWLINGS, J.O.; MILLER, P.A. Genotype by environment interactions in cotton; their nature and related environmental variables. Crop Science, Madison, 9: $377-81,1969 \mathrm{~b}$.

ALLARD, R.W. Relationship between genetic diversity and consistency of performance in different environments. Crop Science, Madison, 1 : 127-33, 1961.

ALLARD, R.W. \& BRADSHAW, A.D. Implications of genotype environmental interactions in applied plant breeding. Crop Science, Madison, $\underline{1}$ : 503-8, 1964.

ALLARD, R.W. Princípios de melhoramento genético de plantas. São Paulo, Edgard Blưcher, 1971. 381p. 
BASSINELLO, A.I. Interação de genötipos $x$ ambientes em ca na-de-açúcar. Piracicaba, 1984. 110p. (Mestrado-Escola Superior de Agricultura "Luiz de Queiroz"/USP).

BRIDGE, R.R.; MEREDITH Jr., W.R.; CHISM, J.F. Variety environment interactions in cotton variety test in the Delta of Mississippi. Crop Science, Madison, 9: 837-8, 1969.

BYTH, D.E.; EISEMANN, R.L.; DE LACY, H.I. Twoway pattern analysis of a large data set to evaluate genotype adaptation. Heredity, London, 37: 215-30, 1976.

CAMPBELL, L.G. \& LAFEVER, H.N. Cultivar $x$ environment interaction in sof red winter yield tests. Crop science, Madison, 17: 604-8, 1977.

CAMPOS, H. Estatistica aplicada a experimentação com canade-açúcar. Piracicaba, FEALQ, 1984. 242p.

COCHRAN, W.G. The Combination of Estimates from Different Experiments. Biometrics, 10: 101-129, 1954.

CORDEIRO, C.M.T. Estudo do Zoneamento da Região Centro-Sul do Brasil para a Cultura do Milho. Brasilia, Universida de de Brasilia, 1978. 104p. (Dissertação de Mestrado).

CORREIA DA SILVA, E. Classificações ambientais para controlar a interação genótipo x ambiente com aplicação à cultū ra do Trigo (Triticum aestivum I.) no Rio grande do sul. Piracicaba, 1981. 76p. (Doutorado - Escola Superior de Agricultura "Luiz de Queiroz"/USP).

EBERHART, S.A. \& RUSSELL, W.A. Stability parameters for comparing varieties. Crop Science, Madison, $\underline{6}$ : 36-40, 1966. 
FALCONER, D.S. Introducción a la genetica quantitativa. México, Ed. CEGSA, 1983. 430p.

FINLAY, K.W. \& WILKINSON, G.N. The analysis of adaptation in plant breeding program. Australian Journal of Agricultural Research, Victōria, 14: 742-54, 1963.

FREEMAiN, G.H. Statistical methods for the analysis of genotype-environment interactions. Heredity, London, 31: 399$54,1973$.

HORNER, T.W. \& FREY, K.J. Methods for determining natural area for oat varietal recomendations. Agronomy Journal, Madison, 49: 313-5, 1957.

IGNACZAK, J.C. \& SILVA, J.G.C. da. Análise conjunta de grupos de experimentos com alguns locais e tratamentos não comuns. Pesquisa Agropecuária Brasileira, Rio de Janeiro, 13: $59-66,1978$.

KOHEL, R.J. Phenotypic stability of homozygous parents and their $F_{1}$ hybrids in upland cotton (Gossypium hirsutum L.). Crop Science, Madison, 9 : 85-8, 1969.

LEMOS, M.A. Variabilidade fenotipica em híbridos simples, hibridos duplos, variedades e compostos de milho (Zea mays L.). Piracicaba, 1976. 62p. (Doutorado - Escola Superior de Agricultura "Luiz de Queiroz"/USP).

MCCALL, L.L.; LAVAL, M.V.; MCiNEW, R.W. Gentype environment study of lock tenacity in uplant cotton. Crop science, Madison, $22(4): 794-7$, 1982 .

MILLER, P.A.; ROBINSON, H.F.; POPE, O.A. Cotton variety testing; additional information on variety $x$ environment interactions. Crop Science, Madison, 2 : 349-52, 1962. 
MILLER, P.A.; WILIIAMS, J.C.; ROBINSON, H.F. Variety $x$ environment interactions in cotton variety test and their implications on testing methods. Agronomy Journal, Madison, 51: 132-4, 1959.

MOTA, F.S. da; BEIRSFORF, M.I.C.; COSTA, M.J.C.; MOTA, W.A.; WESTHPHALEN, S.L. Zoneamento agroclimático do Rio Grande do sul e Santa Catarina. Pelotas, Instituto de Pesqui sa Agropecuária do Sul, 1974. 12lp.

OLIVEIRA, A.C. Comparação de alguns métodos de determinação da estabilidade em plantas cultivadas. Brasilia, 1976. 64p. (Mestrado - Universidade Nacional de Brasilia).

OMRAM, A.O.; MUSTAFA, S.; ABED, S.M. Genotype environment interaction and stability of yield performance in the southern cotton growing. Zone of Nigeria. Cotton ef Fibres Tropicais, Paris, 38: 216-20, 1983.

PARAGUAI. Ministério de Agricultura y Ganaderia. Informe Anual; 1985/86. Asunción, 1987. 260p.

PARAGUAI. Ministério de Agricultura y Ganaderia. Algodon; reunión tecnica. Asunción, Instituto Agronômico Nacional/ PIEA, 1987. 65p.

PEIXOTO, T.C.; SILVA, J.G.C. da; BARRETO, J.N. Técnicas de análises de interação genótipo $x$ ambiente e sctabilidade de clones de cana-de-açücar. In: SIMPÓSIO DE ESTAT'¿STICA APLICADA A EXPERIMENTAÇÃO AGRONÔMICA, 1. e REUNIÃO ANUAL DA REGI ̃O BRASILEIRA DA SOCIEDADE INTERNACIONAL DE BIOMETRIA, 30., Piracicaba, 1985. Anais, Campinas, Fundação Cargill, 1985. p.243-58. 
RERKINS, J.M. \& JINKS, J.L. Environmental and genotype environmental components of variability. III. Multiple lines and crosses. Heredity, London, 23: 339-56, 1968.

PIMENTEL GOMES, F. Curso de estatistica experimental, 6ạ ed. , São Paulo, Nobel, 1985. 430p.

PLAISTED, R.L. \& PETERSON, L.C. A technic for evaluating the ability of selections to yield consistently in different locations or season. American Potato, Washington, 36: $381-5,1959$.

QUISENBERRY, J.E. \& KOHEL, R.J. Phenotypic stability of cot ton. Crop Science, Madison, 11: 837-9, 1971.

RAO, R.C. Advances statistical methods in biometric research. New York, John Wiley \& Sons, 1952. 390p.

ROSITO, C. Interação genótipos $x$ locais em trigo (Tréticum aestivum L.) no Rio Grande do Sul. Piracicaba, 1974. 55p. (Mestrado - Escola Superior de Agricultura "Luiz de Queiroz/USP).

RUSCHEL, R. Interação genótipo x localidade na região centro sul em milho (Zea mays L.). Piracicaba, 1968. 60p. (Mestrado - Escola Superior de Agricultura "Luiz de Quei roz"/USP).

SANTANA, J.C.F. de; CAVALCANTI, F.B.; SANTOS, E.P. Parâmetros de estabilidade na comparação de cultivares de algodoeiro herbāceo (Gossypium hirsutum L.). Pesquisa Agrope cuāria Brasileira, Rio de Janeiro, 18: 261-7, 1983. 
SILVA, J.G.C. \& BARRETO, J.N. Aplicação de regressão linear segmentada em estudos da interação genótipo $x$ ambiente. In: 19. Simpósio de Estatistica Aplicada à Experimentação Agro nômica. Resumos. Campinas, Fundação Cargill, pp.49-50.

SILVA, W.I.; I.T. MIRANDA \& P.G. VIEGAS. Estimativas do pro gresso genético médio em ensaios de cultivares de milho. Bragantia. Campinas, 22: 247-258, 1963.

SEIF, E.; J.C. EVANS; L.N. BALAAM. A multivariate procedure for classifying environments according to their interaction with genotypes. Australian Journal of Agricultural Research. Melbourne, 30: 1021-1026, 1979.

SINGH R.K. \& CHAUDHARY, B.D. Biometrical methods in quantitative genetic analysis. s.1., Kalyani Publisher, 1979. $304 \mathrm{p}$.

SING, T.H. \& GILL, S.S. Genetic diversity in upland cotton under different environments. Indian Journal Genetics and Plant Breeding, New Delhi, 44:506-13, 1984.

SOKAL, R.R. Distance as a measure of taxonomy similarity. Systematic Zool., 10: 70-79, 1969. 253p.

SOKAL, R.R. \& SNEATH, P.H.A. Principles of Numerical Taxonomy. San Francisco, W.H. Freedman and Company, 1973. $573 \mathrm{p}$.

STEEL, R.G.D. \& TORRIE, J.H. Principles and procedures of statistics. New York, McGraw - Hill Book, 1960. 481 p.

TAI, G.C.C. Genotypic stability analisys and its a application to potato regional trials. Crop Science, Madison, 11: $184-90,1971$. 
VENCOVSKY, R. Principios de genética quantitativa. Piracicaba, ESALQ/USP, Departamento de Genética, 1977. 97p.

VENCOVSKY, R. \& GERALDI, I.O. Um modelo multiplicativo apli cado à análise de produção de grãos. Relatório Científico do Departamento de Genética, Piracicaba, 11: $157-65$, 1977 .

VENCOVSKY, R. Herança quantitativa. In: PATERNIANI, E., coord. Melhoramento e produção do milho no Brasil. Campi nas, Fundação Cargill, 1978. Cap. 5, p.122-95.

VERMA, M.M.; CHAHAL, G.S.; MURTY, B.R. Limitations of conventional regression analysis. A proposed modification. Theoretical Applied Genetics, Berlin, 53: 89-91, 1978.

VERHALEN, L.M. \& MURRAY, J.C. A diallel analysis of several fiber property traits in upland cotton (Gossypium hir sutum L.); II. Crop Science, Madison, 9: 311-5, 1969.

YATES, F. \& COCHRAN, W.G. The analysis of group of experiments. Journal of Agricultural Science, London, 28: 556$80,1938$.

WRICKE, G. Zur Berechning der okovalenz bei sommerweizen und hafer. Z.F. Pflanzenzuchtung, 52: 127-138, 1965. 
83.

$\underline{\mathrm{A}} \underline{\mathrm{P}} \underline{\mathrm{E}} \underline{\mathrm{N}} \underline{\mathrm{D}} \underline{\mathrm{I}} \underline{\mathrm{E}}$ 
84.

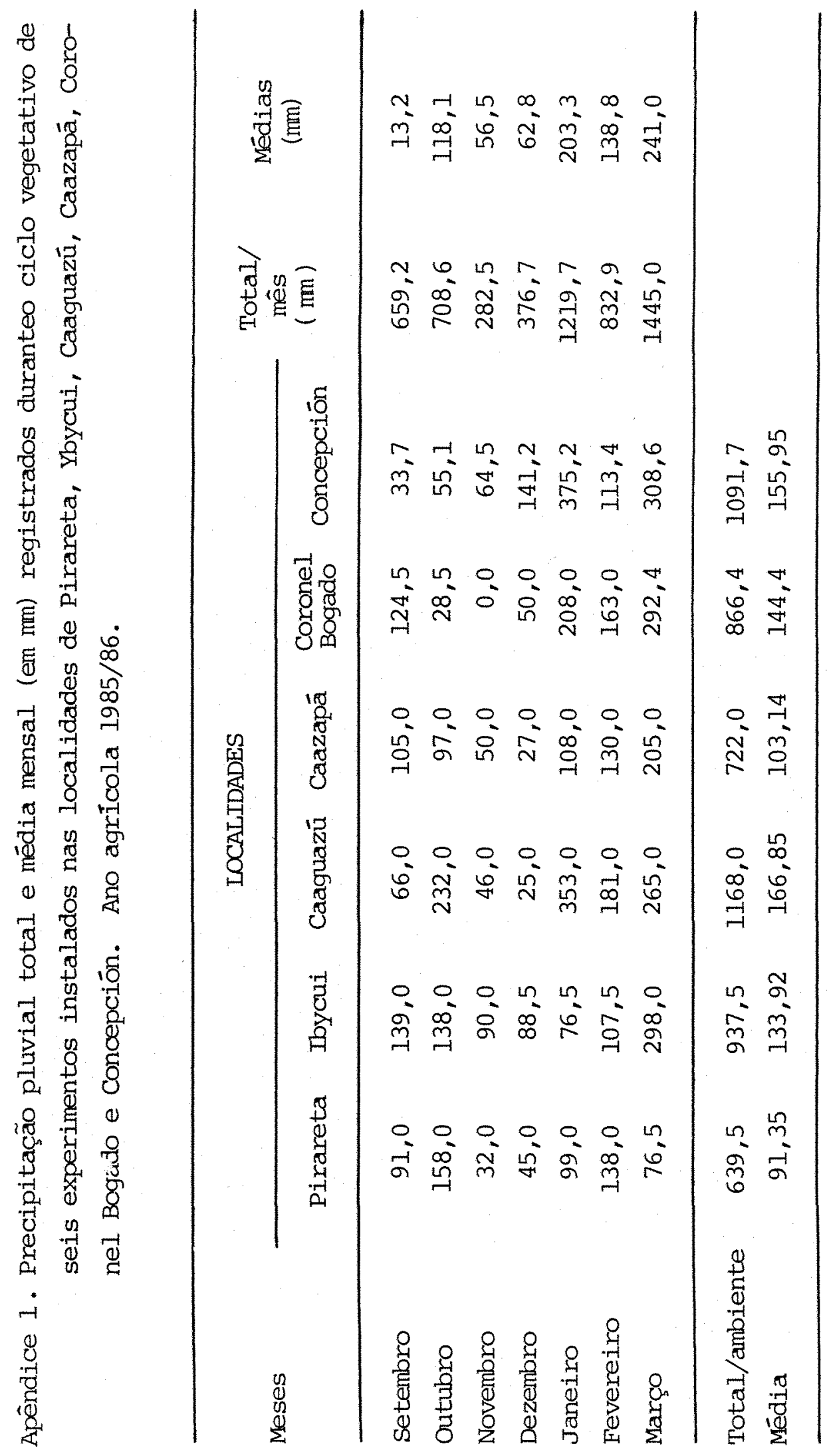


85.

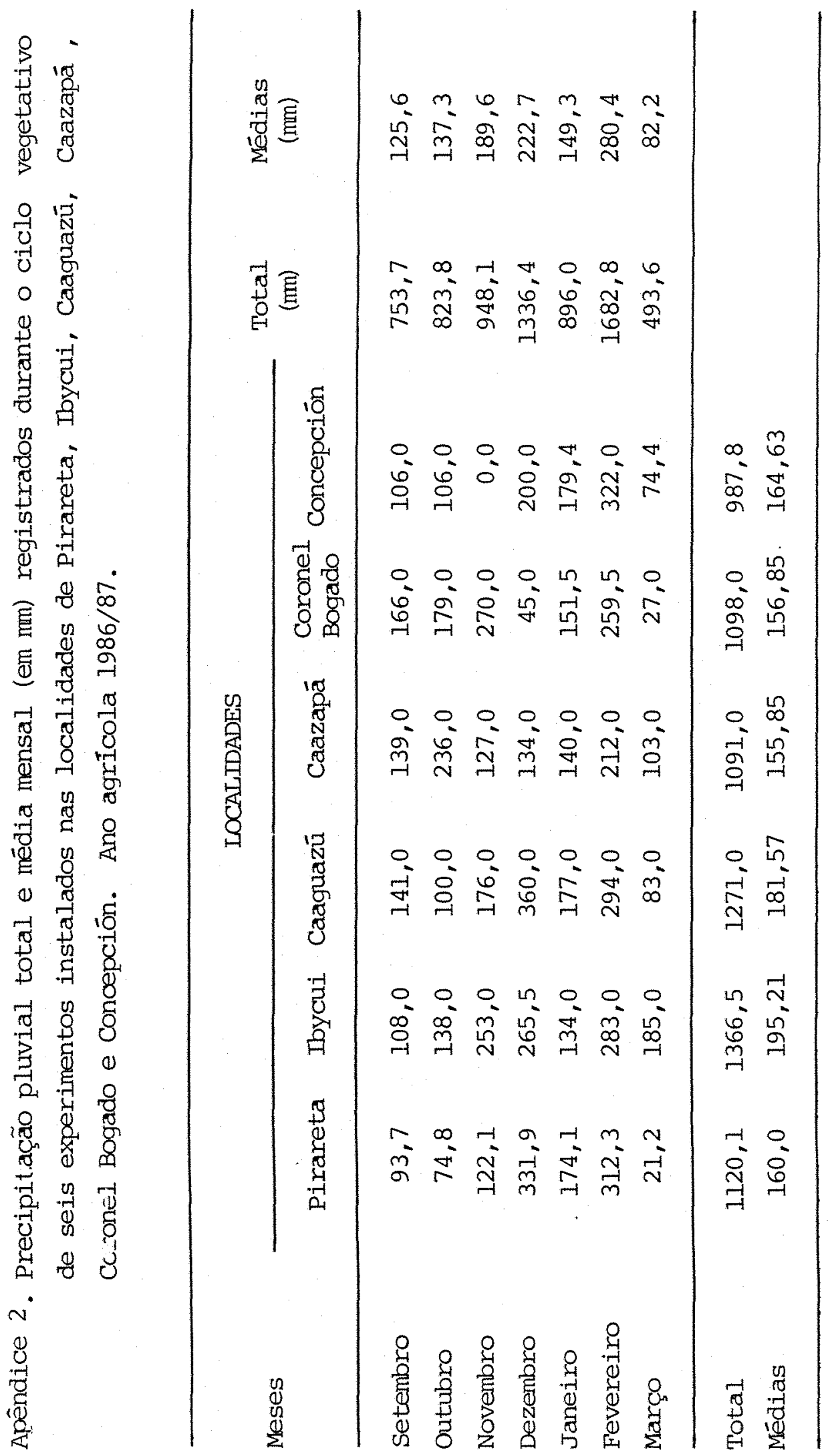


Apêndice 3. Análise da variância em blocos ao acaso com oito repetições para produtividade de algodão em caro ço em kg/20m ${ }^{2}$ referente a três genótipos, da localidade de Pirareta, média $(\bar{y})$ e coeficiente de variação (CV \%). Ano agrícola 1985/86.

\begin{tabular}{lcccc}
\hline F.V. & G.L. & S.Q. & Q.M. & F \\
\hline Blocos & 7 & 0,1382 & 0,020 & 0,9 \\
Genótipos & 2 & 0,0843 & 0,042 & $2,0 \mathrm{~ns}$ \\
Resĩduo & 14 & 0,2932 & 0,021 & \\
\hline TOTAL & 23 & 0,5157 & \\
\hline C.V. $(\%)=6,61$ & & $\bar{y}=2,19$
\end{tabular}

Apêndice 4. Análise da variância em blocos ao acaso com oito repetições para produtividade de algodão em caro ço em kg/20m ${ }^{2}$ referente a três genótipos, da localidade de Ybycui, média $(\bar{y})$ e coeficiente de variação (CV \%). Ano agrícola 1985/86.

\begin{tabular}{lcccc}
\hline F.V. & G.L. & S.Q. & Q.M. & F \\
\hline Blocos & 7 & 2,9823 & 0,426 & 5,3 \\
Genótipos & 2 & 0,9643 & 0,482 & $6,0 *$ \\
Residuo & 14 & 1,1176 & 0,080 & \\
\hline TOTAL & 23 & 5,0642 & \\
\hline C.V. (.०) $=6,64$ & & $\bar{y}=4,25$ &
\end{tabular}


Apêndice 5. Anālise da variância em blocos ao acaso com oito repetições para produtividade de algodão em caro ço em $\mathrm{kg} / 20 \mathrm{~m}^{2}$ referente a três genōtipos, da localidade de Caaguazú, média $(\bar{y})$ e coeficiente de variação (CV \%). Ano agrícola 1985/86.

\begin{tabular}{lcccc}
\hline F.V. & G.L. & S.Q. & Q.M. & F \\
\hline Blocos & 7 & 1,4295 & 0,204 & 1,3 \\
Genótipos & 2 & 2,0164 & 1,008 & $6,2 *$ \\
Residuo & 14 & 2,2736 & 0,162 & \\
\hline TOTAL & 23 & 5,7195 & & \\
\hline C.V. (०) $=8,26$ & & $\bar{y}=4,87$ &
\end{tabular}

Apêndice 6. Anālise da variância em blocos ao acaso com oito repetições para produtividade de algodão em caro ço em $\mathrm{kg} / 20 \mathrm{~m}^{2}$ referente a três genótipos, da localidade de Caazapa, média $(\bar{y})$ e coeficiente de variação (C.V. \%). Ano agrícola 1985/86.

\begin{tabular}{lcccc}
\hline F.V. & G.I. & S.Q. & Q.M. & F \\
\hline Blocos & 7 & 4,0902 & 0,584 & 8,7 \\
Genótipos & 2 & 1,7946 & 0,892 & $13,2 *$ \\
Residuo & 14 & 0,9455 & 0,068 & \\
\hline TOTAL & 23 & 6,8203 & & \\
\hline C.V. (ㅇ) $=8,58$ & & $\bar{y}=3,04$ &
\end{tabular}


Apêndice 7. Análise da variância em blocos ao acaso com oito repetições para produtividade de algodão em caro ço em $\mathrm{kg} / 20 \mathrm{~m}^{2}$ referentes a três genótipos da localidade de coronel Bogado, média $(\bar{y})$ e coeficientre de variação (C.V. \%). Ano agrícola 1985/ 86.

\begin{tabular}{lcccc}
\hline F.V. & G.L. & S.Q. & Q.M. & F \\
\hline Blocos & 7 & 0,3410 & 0,049 & 2,3 \\
Genótipos & 2 & 0,0138 & 0,007 & $0,3 \mathrm{~ns}$ \\
Residuo & 14 & 0,2947 & 0,021 & \\
\hline TOTAL & 23 & 0,6496 & \\
\hline C.V. $\left(. \frac{\circ}{0}\right)=8,05$ & & $\bar{Y}=1,80$ &
\end{tabular}

Apênaice 8. Anālise da variância em blocos ao acaso com oito repetições para produtividade de algodão em caró ço em $\mathrm{kg} / 20 \mathrm{~m}^{2}$ referentes a três genótipos da localidade de concepción, média $(\bar{y})$ e coeficiente de variação (C.V. \%). Ano agrícola 1985/86.

\begin{tabular}{lcccc}
\hline F.V. & G.L. & S.Q. & Q.M. & F \\
\hline Blocos & 7 & 4,9092 & 0,701 & 1,9 \\
Genótipos & 2 & 0,0901 & 0,045 & 0,1 ns \\
Residuo & 14 & 5,1448 & 0,367 & \\
\hline TOTAL & 23 & 10,1442 & \\
\hline C.V. $(\%)=10,25$ & $\bar{Y}=5,92$ &
\end{tabular}


Apêndice 9. Análise da variância em blocos ao acaso com quatro repetições para produtividade em $\mathrm{kg} / 20 \mathrm{~m}^{2}$ de algodão em caroço, referentes a nove genótipos da localidade de Pirareta, média $(\bar{y})$ e coeficiente de variação (C.V. \%). Ano agrỉcola 1986/87.

\begin{tabular}{lcrrc}
\hline F.V. & G.L. & S.Q. & Q.M. & F \\
\hline Blocos & 3 & 17,3015 & 5,767 & 13,9 \\
Genótipos & 8 & 7,1964 & 0,900 & $2,2 \mathrm{~ns}$ \\
Residuo & 24 & 9,9733 & 0,416 & \\
\hline TOTAL & 35 & 34,4712 & & \\
\hline C.V. $(\%)=13,05$ & $\bar{y}=4,94$ &
\end{tabular}

Apêndice 10. Anālise da variância em blocos ao acaso com qua tro repetições para produtividade em $\mathrm{kg} / 20 \mathrm{~m}^{2}$ de algodão em caroço, referente a nove genótipos da localidade de Ybycui, média $(\bar{y})$ e coeficiente de variação (C.V. o). Ano agrícola 1986/87.

\begin{tabular}{lcccc}
\hline F.V. & G.L. & S.Q. & Q.M. & $F$ \\
\hline Blocos & 3 & 1,3810 & 0,460 & 4,2 \\
Genótipos & 8 & 3,3281 & 0,417 & $3,8 *$ \\
Residuo & 24 & 2,6609 & 0,111 & \\
\hline TOTAL & 35 & 7,3701 & \\
\hline C.V. (.\%) $=7,85$ & & $\bar{Y}=4,24$ &
\end{tabular}


Apêndice 11. Análise da variância em blocos ao acaso com qua tro repetições para produtividade em $\mathrm{kg} / 20 \mathrm{~m}^{2}$ de algodão em caroço, referentes a nove genótipos da localidade de Pirareta, média $(\bar{y})$ e coeficiente de variação (CV \%). Ano agrícola 1986/87.

\begin{tabular}{lcccc}
\hline F.V. & G.L. & S.Q. & Q.M. & F \\
\hline Blocos & 3 & 5,5831 & 1,861 & 8,9 \\
Genótipos & 8 & 1,1761 & 0,223 & 1, Ins \\
Residuo & 24 & 4,9913 & 0,208 & \\
\hline TOTAL & 35 & 12,3606 & & \\
\hline C.V. $(\%)=7,35$ & & $\bar{Y}=6,20$ &
\end{tabular}

Apêndice 12. Análise da variância em blocos ao acaso com qua tro repetições para produtividade em $\mathrm{kg} / 20 \mathrm{~m}^{2}$ de algodão em caroço, referentes a nove genótipos da localidade de Concepciōn, média $(\bar{y})$ e coeficiente de variação (CV\%). Ano agrícola 1986/87.

\begin{tabular}{lcrll}
\hline F.V. & G.I. & S.Q. & Q.M. & F \\
\hline Blocos & 3 & 0,3767 & 0,126 & 0,3 \\
Genótipos & 8 & 16,7980 & 2,100 & $5,5 * *$ \\
Residuo & 24 & 9,1151 & 0,380 & \\
\hline TOTAL & 35 & 26,2898 & \\
\hline C.V. $\left(\frac{\circ}{\circ}\right)=9,87$ & $\bar{Y}=6,24$
\end{tabular}


Apêndice 13. Análise da variância em blocos ao acaso com qua tro repetições para produtividade em $\mathrm{kg} / 20 \mathrm{~m}^{2}$ de algodão em caroço, referentes a nove genótipos da localidade de Caaguazú, média $(\bar{y})$ e coeficiente de variação (CVo). Ano agrícola 1986/87.

\begin{tabular}{lcccc}
\hline F.V. & G.L. & S.Q. & Q.M. & F \\
\hline Blocos & 3 & 1,2091 & 0,403 & 3,4 \\
Genótipos & 8 & 3,9985 & 0,500 & $4,2 *$ \\
Resíduo & 24 & 2,8671 & 0,119 & \\
\hline TOTAL & 35 & 8,0747 & \\
\hline C.V. (은 $=10,14$ & $\bar{y}=3,79$ &
\end{tabular}

Apêndice 14. Análise da variância em blocos ao acaso com qua tro repetições para produtividade em $\mathrm{kg} / 20 \mathrm{~m}^{2}$ de algodão em caroço, referentes a nove genótipos da localidade de Caazapa, média $(\bar{y})$ e coeficiente de variação (CV\%). Ano agrícola 1986/87.

\begin{tabular}{lcrrr}
\hline F.V. & G.L. & S.Q. & Q.M. & F \\
\hline Blocos & 3 & 13,5037 & 4,501 & 16,5 \\
Genótipos & 8 & 4,0873 & 0,511 & $1,9 \mathrm{~ns}$ \\
Residuo & 24 & 6,5410 & 0,273 & \\
\hline TOTAL & 35 & 24,1320 & \\
\hline C.V. $\left(\frac{\circ}{0}\right)=7,0$ & $\bar{y}=7,46$ &
\end{tabular}

